Article

\title{
Online Chemical Characterization and Source Identification of Summer and Winter Aerosols in Măgurele, Romania
}

\author{
Luminiţa Mărmureanu $^{1} \mathbb{D}$, Jeni Vasilescu ${ }^{1, *(D)}$, Jay Slowik ${ }^{2} \mathbb{D}$, André S. H. Prévôt ${ }^{2}$, \\ Cristina Antonia Marin 1,3 (D), Bogdan Antonescu 1(D), Athanasia Vlachou ${ }^{2}$, Anca Nemuc ${ }^{1}$, \\ Alexandru Dandocsi ${ }^{1,3}$ (iD) and Sönke Szidat 4 (D) \\ 1 Remote Sensing Department, National Institute of Research and Development for \\ Optoelectronics INOE 2000, Str. Atomiştilor 409, Măgurele, RO077125 Ilfov, Romania; \\ mluminita@inoe.ro (L.M.); cristina.marin@inoe.ro (C.A.M.); bogdan.antonescu@inoe.ro (B.A.); \\ anca@inoe.ro (A.N.); alexandru.dandocsi@inoe.ro (A.D.) \\ 2 Laboratory of Atmospheric Chemistry, Paul Scherrer Institute, 5232 Villigen PSI, Switzerland; \\ jay.slowik@psi.ch (J.S.); andre.prevot@psi.ch (A.S.H.P.); athanasia.vlachou@psi.ch (A.V.) \\ 3 Department of Physics, Politehnica University of Bucharest, Str. Spl. Independenţei 313, \\ RO061071 Bucureşti, Romania \\ 4 Department of Chemistry and Biochemistry and Oeschger Centre for Climate Change Research, \\ University of Bern, 3012 Bern, Switzerland; soenke.szidat@dcb.unibe.ch \\ * Correspondence: jeni@inoe.ro
}

Received: 10 March 2020; Accepted: 8 April 2020; Published: 14 April 2020

check for updates

\begin{abstract}
Aerosols and organic source apportionment were characterized using data collected during two measurement campaigns. These campaigns were conducted during the summer and winter seasons at Măgurele, a site located southwest of Bucharest, the capital of Romania and one of the largest cities in southeastern Europe (raking seven in Europe based on population). The summer campaign was conducted between 7 June-18 July 2012, and the winter campaign from 14 January-6 February 2013. Approximately 50\% of the organic fraction contribution to the total submicron particulate matter sampled by aerosol mass spectrometer was evidenced during both seasons. Submicronic organic aerosol sources were quantified using the positive matrix factorization approach. For warm (summer) and cold (winter) seasons, more than 50\% from total organics was represented by oxidized factors. For the summer season, separate analyses were conducted on data influenced by urban and non-urban sources. The influence of pollution from Bucharest on the measurement site was observed in aerosol concentration and composition. The primary organic aerosols have different contribution percentage during summer, depending on their main origin. The influence of Bucharest, during summer, included cooking contribution of $13 \%$. The periods with more regional influence were characterized by lower contribution from traffic and biomass burning in a total proportion of $28 \%$. In winter, the influence of local non-traffic sources was dominant. For more than $99 \%$ of the measurements, the biomass burning indicator, $f 60$, exceeded the background value, with residential heating being an important source in this area. Fossil fuel contribution was confirmed for one week during the winter campaign, when ${ }^{14} \mathrm{C}$ analysis of total and elemental carbon revealed the presence of $17 \%$ fossil contributions to total carbon. Mass spectrometry, ${ }^{14} \mathrm{C}$ and absorption data suggest biomass burning as the predominant primary source of organic aerosols for the winter season.
\end{abstract}

Keywords: aerosol chemical composition; aerosol sources; seasonal characteristics 


\section{Introduction}

Aerosols play an essential role in Earth's radiative budget, and they have been extensively studied in the last decades due to their effects on human health and climate [1,2]. High uncertainties associated to the estimation of atmospheric aerosol properties represent one of the main limitations in climate models [3]. These uncertainties are associated with aerosol composition and concentration, which in turn determine the magnitude of scattering and absorption of solar radiation [4]. Aerosols, known as particulate mater (PM), are classified depending of their size as coarse, with diameter up to $10 \mu \mathrm{m}$ $\left(\mathrm{PM}_{10}\right)$, fine with diameter smaller than $2.5 \mu \mathrm{m}\left(\mathrm{PM}_{2.5}\right)$ and submicronic $\left(\mathrm{PM}_{1}\right)$, particulate matter with a diameter less than $1 \mu \mathrm{m}$. The assessment of submicronic aerosol particles chemical components is crucial because these particles are responsible for scattering of $80 \%$ of the total solar radiation [5], while black carbon (BC) is the main contributor to aerosol optical absorption.

Organic aerosols (OA) represent one of the most important fractions of $\mathrm{PM}_{1}$, contributing about $20 \%-50 \%$ to the total fine aerosol mass [6]. OA originates from a variety of sources, including anthropogenic combustion, biomass burning events, and biogenic emissions [7] with different molecular signature. To date, molecular speciation has been achieved for only $10 \%-30 \%$ of the total ambient organic aerosols, predominantly long alkyl hydrocarbons (e.g., alkenes, polycyclic aromatic hydrocarbons (PAH), alcohols, and acids) [8,9]. Techniques capable of quantitatively describing bulk aerosol concentration and composition, such as on-line mass spectrometry, are essential for characterizing OA sources and aging. The Aerodyne aerosol mass spectrometer (AMS) is widely used recently to assess at high time resolution, chemical speciation, size distribution and sources of submicronic organic aerosols (e.g., [10-12]).

Previous studies have demonstrated the contribution of organic aerosols to $\mathrm{PM}_{1}$, together with other species such as nitrate, sulfate, chloride and ammonium. Megacities like Hong Kong-Shenzhen [13], Beijing [14,15], New York City [16], Toronto [17] have been the subject of previous research related to aerosol composition and their sources. West $[1,12,18,19]$ and South $[20-22]$ European urban and rural sites have been previously characterized assessing the contribution of primary and secondary aerosol sources. Up to now, only few studies have investigated the aerosol chemical properties and their possible sources for Eastern Europe [23,24], and even less in Romania [25,26]. The data analyzed in this paper were collected in Magurele (Romania) as part of a large international field campaign in the frame of the EU project ACTRIS (Aerosols, Clouds, and Trace gases Research InfraStructure; [27]) and EMEP (European Monitoring and Evaluation Programme; [28]) [29,30].

To identify and quantify the sources of aerosol, different methods and techniques (e.g., receptor models, including chemical mass balance) are used. One such method, that is currently widely implemented, is the positive matrix factorization (PMF) [31]. In particular, PMF using the multilinear engine (ME-2, [32]) and configured with the Source Finder (SoFi) interface have been proven to be a powerful approach to OA source apportionment and identification of specific sources of primary organic aerosol (POA), e.g., traffic (hydrocarbon-like organic aerosol, HOA), cooking (COA) and biomass burning (BBOA) [33]. Meanwhile, secondary organic aerosols (SOA) are typically described in terms of their degree of oxygenation, i.e., more oxygenated oxygenated organic aerosols (MO-OOA) or less oxygenated (LO-OOA) (e.g., [34,35]).

The receptor model (i.e., source apportionment analysis) is used in combination with complementary data such as gases concentrations, absorption and scattering measurements, and filter-based elemental composition [33]. In the case of additional filter-based measurements, the carbonaceous component can be divided in elemental carbon and organic carbon [36,37]. Furthermore, recent studies showed that BC is a result of combustion and an excellent indicator of pyrolysis processes of biomass or fossil fuel [38]. Emissions from fossil fuel combustion have been previously described in literature [39,40].

Despite this approach (i.e., source apportionment) being widely used to characterize the sources of aerosols (e.g., traffic, coal combustion, biomass burning) in different environments, and thus providing a complete characterizations of submicronic particles, there is a lack of studies employing 
this approach for Eastern Europe. The aim of the article is to characterize the organic aerosol sources and their time evolution during summer and winter seasons in the southern Romania using the organic receptor model. Thus, we aim to describe the different source contributions to OA and to contribute to a better understanding of aerosol sources over Eastern Europe. In particular, we aim to improve the knowledge about pollution seasonality and variability of the sources at Măgurele to better inform decision makers. Complementary data were used as well to characterize the vertical distribution of aerosols. For example, the planetary boundary layer (PBL) height and its time evolution, as well as the presence of aerosol layers from long-range transport have been assessed using a ground-based multi-wavelength Raman lidar [26,41]. Furthermore, ${ }^{14} \mathrm{C}$ measurements have been performed to validate the results obtained through source apportionment.

This article is structured as follows: Section 2 describes the sampling site, the data, and the approach used, including the main limitations of data analyses. Section 3 provides the seasonal distribution of $\mathrm{PM}_{1}$ fractions (Section 3.1), the aerosol vertical distribution and aerosol concentrations (Section 3.2), and the source apportionment results for warm (Section 3.3.1 for city and Section 3.3.2 for regional influence) and cold season (Section 3.3.3). Section 4 summarizes the results of this article.

\section{Methodologies and Instrumentation}

\subsection{Experimental Site}

Summer and winter measurement campaigns were performed in Măgurele, a peri-urban area located in the southeastern part of Bucharest, capital city of Romania $\left(44.35^{\circ} \mathrm{N}, 26.03^{\circ} \mathrm{E}, 93 \mathrm{~m}\right.$ altitude). Măgurele is situated approximately $11 \mathrm{~km}$ from the center of Bucharest, but still within its industrial and residential sectors. The major aerosol sources influencing the site are seasonally dependent. Residential heating based on wood, coal or methane combustion occurs during the cold season [42]. Several local power plants that are sources of particles and gases [43], mainly fossil fuel-based, are located in Bucharest. According to the environmental permit issued by the Romanian Ministry of Environment [44], the total annual fuel consumption (316,552 tons) per power plant is distributed as follows: $93.59 \%$ natural gas, $6.4 \%$ fuel oil, and $0.01 \%$ diesel fuel. Fuel oil is most commonly used when natural gas pressure is low, generally in winter, when temperatures are below $0{ }^{\circ} \mathrm{C}$. The Măgurele site may also be influenced by industrial emissions, particularly cement stations located approximately $3 \mathrm{~km}$ north from the site, which operate according to market demand (higher during the warm season). Landfills are located $8 \mathrm{~km}$ southwest of the site which can be an important source for biogenic aerosols and smoke due to uncontrolled fires.

With respect to regional-scale emissions, Măgurele is located in the Romanian Plain, an agricultural area and thus a possible source of biomass burning aerosols related to agricultural practices [26]. The region is also influenced by the Carpathian Mountains and the Black Sea. High pressure and warm, humid air masses brought by Mediterranean low pressure systems influence eastern and southern regions of Romania. Romania frequently faces prolonged summer heat wave events due to tropical air masses transported from the Saharan region by the North African high pressure systems. During winter, polar air is generally advected by the Siberian anticyclones $[45,46]$. The PBL, over the region, is often influenced by aerosols that have been transported long distances at this location, including biomass burning aerosols (from Greece, Turkey, Ukraine, and Russia) or mineral dust (from North Africa and Greece) [47,48].

\subsection{Measurement Campaigns}

Two intensive measurement campaigns were conducted in Măgurele as part of the ACTRIS-EMEP (Aerosols, Clouds, and Trace gases Research InfraStructure-European Monitoring and Evaluation Programme) initiative $[29,30]$. The summer campaign was conducted between 7 June-18 July 2012 [49] and the winter campaign from 14 January-6 February 2013 [50]. The main purpose of 
the campaigns was to identify the major sources of summer and winter aerosols near Bucharest using in situ instruments.

\subsection{Instruments}

\subsubsection{Mass Spectrometry}

The Aerodyne compact time-of-flight aerosol mass spectrometer (C-ToF AMS, Aerodyne, United States) measures the chemical composition and size resolved mass concentration of non-refractory $\mathrm{PM}_{1}$ aerosol $\left(\mathrm{NR}-\mathrm{PM}_{1}\right)$. The C-ToF AMS operation is described extensively in the literature [51], and only a brief summary is given here. Thus, particles are continuously sampled through a $100 \mu \mathrm{m}$ critical orifice into a series of aerodynamic lens, which focuses the particles into a narrow beam and accelerates them to a velocity that is inversely related to their vacuum aerodynamic diameter. The particle beam can be either alternately blocked and unblocked (mass spectrum mode) to obtain the mass spectrum of the particle ensemble, or modulated by a spinning chopper wheel (particle time-of-flight mode) to obtain size-resolved mass spectra at reduced sensitivity. In either case, particles impacted a resistive heating tungsten surface at $600^{\circ} \mathrm{C}$, at which the non-refractory components vaporize, and then were ionized by electron ionization $(70 \mathrm{eV})$ and subsequently detected by a time-of-flight mass spectrometer.

Aerosol measurements were performed every 10 min during the summer campaign and every 2 min during the winter campaign. The sampling period was split equally between the mass spectrum and the particle time-of-flight mode, with daily checks of $m / z$, electron multiplier and time of flight. The AMS ionization efficiency was determined before each campaign, using $\mathrm{NH}_{4} \mathrm{NO}_{3}$ particles. The values obtained were $7.37 \times 10^{-7}$ and $4.22 \times 10^{-7}$ ions per molecule for summer and winter, respectively. The RIE values used were: 1.4 for $\mathrm{Org}, 1.1$ for $\mathrm{NO}_{3}$ and 1.3 for $\mathrm{Chl}, 4$ for $\mathrm{NH}_{4}$ and 1.2 for $\mathrm{SO}_{4}$, and the collection efficiency was 1 . All measurements were performed using a $\mathrm{PM}_{2.5}$ cyclone and a copper sampling line. The data were processed and analyzed using Squirrel software (SeQUential Igor RetRiEvaL, D. Sueper, University of Colorado-Boulder-version 1.56)) developed in the Igor environment (version 6.3.6.4, Wavemetrics, Inc., Oswego, OR, USA). Standard data processing procedures were used (i.e., $m / z$ calibration, baseline subtraction, air beam correction) as discussed previous (e.g., [52]). The uncertainty associated with the AMS measurements of mass concentration has previously described in the literature $[53,54]$ as $\pm 38 \%$ accuracy which is consistent over in time.

\subsubsection{Collocated Measurements}

The PBL height variations in time were investigated using a multi-wavelength Raman lidar system (Raymetrics, Greece). The lidar system measures three times per week and during special events following the EARLINET schedule [26], but continuously measurements have been performed between 9-12 July 2012 [55]. The system has a vertical resolution of $3.75 \mathrm{~m}$ and detection in 7 channels 1064, 532 parallel, 532 cross, 355, 607, 387 and $408 \mathrm{~nm}$. The backscatter coefficients (1064, 532, $355 \mathrm{~nm})$, extinction coefficients $(532,355 \mathrm{~nm})$ and linear particle depolarization ratio $(532 \mathrm{~nm})$ of aerosols between 0.8 and $8 \mathrm{~km}$ altitude are used to assess the aerosol optical properties [47]. The PBL height values were computed using the gradient method [41].

The gas monitors (APNA-370 Ambient $\mathrm{NO}_{x}$ Monitor and APSA-370 Ambient Sulfur Dioxide Monitor, HORIBA, Japan) were used during the winter campaign to measure $\mathrm{SO}_{2}$ and $\mathrm{NO}_{x}$ concentrations. The $\mathrm{SO}_{2}$ monitor principle is based on the ultraviolet fluorescence method, where the gas samples are excited using the $214 \mathrm{~nm}$ wavelength. The emitted light, in the range of $300-400 \mathrm{~nm}$, is proportional to the $\mathrm{SO}_{2}$ concentration. The $\mathrm{NO}_{x}$ monitor measures gas concentrations using a cross-flow modulated chemiluminescence method. The sensitivity for $\mathrm{SO}_{2}$ is in the $0-0.5 \mathrm{ppm}$ range, while $\mathrm{NO}, \mathrm{NO}_{2}, \mathrm{NO}_{x}$ in the $0-1 \mathrm{ppm}$ range. Zero and span calibrations were performed at the beginning of the winter campaign in order to have accurate data [56]. 
Particle optical absorption was measured during the winter (31 January-6 February) using a 7-wavelength (370, 470, 525, 590, 660, 880, $950 \mathrm{~nm}$ ) dual spot Aethalometer (AE33, Magee Scientific Inc., United States) [57], that continuously samples aerosols on a quartz filter and derives the optical absorption with $1 \mathrm{~s}$ time resolution [37,38]. In this article, the specific wavelengths $\lambda_{1}=470 \mathrm{~nm}$ and $\lambda_{2}=880 \mathrm{~nm}$ were exploited due to their particular sensitivity to black carbon resulted from biomass burning (wood burning) in the UV domain and traffic related aerosols (fossil fuel) in IR domain, respectively [58]. Based on Equations (1)-(7), the BC resulted from wood combustion and BC resulted from fossil fuel combustion were separated [59]. Note these equations assume negligible absorption at these wavelengths from all sources except wood burning and traffic.

$$
\begin{gathered}
\frac{b_{a b s}\left(\lambda_{U V}\right)_{f f}}{b_{a b s}\left(\lambda_{I R}\right)_{f f}}=\left(\frac{\lambda_{U V}}{\lambda_{I R}}\right)^{-\alpha_{f f}} \\
\frac{b_{a b s}\left(\lambda_{U V}\right)_{w b}}{b_{a b s}\left(\lambda_{I R}\right)_{w b}}=\left(\frac{\lambda_{U V}}{\lambda_{I R}}\right)^{-\alpha_{w b}} \\
b_{a b s}(\lambda)=b_{a b s}(\lambda)_{f f}+b_{a b s}(\lambda)_{w b} \\
b_{a b s}\left(\lambda_{U V}\right)_{w b}=\frac{1}{1-\left(\frac{\lambda_{U V}}{\lambda_{I R}}\right)^{-\alpha_{f f}} *\left(\frac{\lambda_{U V}}{\lambda_{I R}}\right)^{-\alpha_{w b}}} \cdot\left[b_{a b s}\left(\lambda_{U V}\right)-\left(\frac{\lambda_{U V}}{\lambda_{I R}}\right)^{-\alpha_{f f}} * b_{a b s}\left(\lambda_{I R}\right)\right] \\
b_{a b s}\left(\lambda_{I R}\right)_{w b}=\left(\frac{\lambda_{U V}}{\lambda_{I R}}\right)^{\alpha_{w b}} * b_{a b s}\left(\lambda_{U V}\right)_{w b} \\
b_{a b s}\left(\lambda_{U V}\right)_{f f}=b_{a b s}\left(\lambda_{U V}\right)-b_{a b s}\left(\lambda_{U V}\right)_{w b} \\
b_{a b s}\left(\lambda_{I R}\right)_{f f}=b_{a b s}\left(\lambda_{I R}\right)-b_{a b s}\left(\lambda_{I R}\right)_{w b}
\end{gathered}
$$

where $b_{a b s}\left(\lambda_{U V}\right)_{w b}, b_{a b s}\left(\lambda_{I R}\right)_{w b}, b_{a b s}\left(\lambda_{U V}\right)_{f f}, b_{a b s}\left(\lambda_{I R}\right)_{f f}$ are absorption coefficients at the UV and IR wavelengths associated with wood burning (wb) and fossil fuel combustion (ff); $\alpha_{f f}=1.0$ (fossil) [60] and $\alpha_{w b}=2.0$ (wood) [61]. Black carbon concentrations related to wood burning $\left(B C_{w b}\right)$ and fossil fuel combustion $\left(B C_{f f}\right)$ are derived using the mass absorption cross sections and the associated absorption coefficients.

Humidity, temperature, wind speed and direction, were monitored with the Environdata Weather Master 2000 station (Warwick Qld, Australia). The air masses origins and possible regional sources have been assessed using the back trajectories from the HYSPLIT model [62] and MODIS fire maps [63], using the same protocol as in Nicolae et al. [26].

\subsubsection{Radiocarbon Analysis}

During the winter campaign, a low-volume sampler (Low Volume Sampler-LVS3, LECKEL, Germany) was used to collect daily $\mathrm{PM}_{2.5}$ particles on quartz filters (24 h average, $55.18 \mathrm{~N} \mathrm{~m}^{3}$, $2.3 \mathrm{~m}^{3} \mathrm{~h}^{-1}$ ). The collected samples were analyzed for organic and elemental carbon. Radiocarbon measurements were performed at the LARA laboratory at the University of Bern, Switzerland [64]. ${ }^{14} \mathrm{C}$ was measured in total carbon and elemental carbon, from which ${ }^{14} \mathrm{C}$ of organic carbon was determined by isotope mass balance. This allows a quantitative distinction between particulate carbon originating from fossil (F) and non-fossil (NF) sources. Source apportionment of elemental carbon based on ${ }^{14} \mathrm{C}$ analysis has been described in details previously papers [11,36,65].

\subsubsection{Source Apportionment Analysis}

Source apportionment was conducted on AMS organic mass spectra using positive matrix factorization [66] implemented through the ME2 solver. The SoFi interface versions 4.8 and 5.1, implemented within IGOR Pro software, were used for model configuration and post-analysis [33,34,67]. PMF resolves the measured time series of organic mass spectra as a linear combination of a set of static factor mass spectra, and their time-dependent intensities. The factors 
represent the atmospheric emissions sources or aging processes. This can be expressed as the matrix equation $X=G \cdot F+E$, here $X$ denotes the input data matrix (time $\cdot m / z), G$ contains the factor time series (time $\cdot$ factor), $F$ contains the factor profiles $($ factor $\cdot m / z)$, and $E$ the model residuals $($ time $\cdot m / z)$ not explained by $G \cdot F$.

PMF solutions may not be mathematically unique and other solutions may exist, depending on rotational ambiguity. This rotational ambiguity makes it non-trivial to retrieve an environmentally optimal solution, in which all major sources are accounted for and separated from each other. To efficiently explore the solution space, we constrain the factor profiles (elements of $F$ ) of certain sources known to influence the sampling site according to source profiles obtained in other ambient studies. This was implemented via the $a$-value approach, in which an output profile is allowed to vary from its input profile by a factor of $a$ at each $m / z$. The $a$-value approach has been successfully used in a number of AMS PMF analyses (e.g., $[68,69]$ ) and has been shown to provide improved performance relative to unconstrained PMF [33].

Input matrices (data and uncertainties) were calculated in Squirrel v1.56 [70]. We applied PMF pre-processing procedures recommended by Ulbrich et al. [71] as follows. For both seasons, a minimum error of 1 ion was applied. Variables with a signal to noise ratio (SNR) between 2 and 0.2 were downweighted by a factor of 2 , while variables with SNR $<0.2$ were downweighted by a factor of 10. The summer dataset contains $m / z$ between 12 to 125; higher $m / z$ were excluded due low SNR. The winter dataset has higher SNR and therefore contain $m / z$ from 12 to 300. At $m / z 29$ and 30 , we identified additional uncertainty due to imperfections and/or variability in the subtraction of air contributions (based on fragmentation of $\mathrm{N}^{2+}$ at $m / z 28$ ). Consequently, these $m / z$ were downweighted for the winter dataset and removed from the summer dataset.

Analysis of the PMF solutions follows the framework proposed by Crippa et al. [72]. Seasonal variability of chemical composition and source contribution was observed and highlighted accordingly. The data analysis described by Canonaco et al. [73] was based on an inspection of source dependent markers. The model configuration was set up differently to account for seasonal differences. For the summer dataset, first PMF analysis without constraining factors was performed. This approach yielded two SOA factors and three POA factors (HOA, COA, and BBOA). The diurnal variations, time series, and spectra of primary factors derived from the PMF model indicate the mixing among sources. The separation of the POA factors was made constraining the data with spectra from Paris [12]. The approach, to separate POA factors, failed because the COA contribution was very low, the HOA factor retained a meal-time (i.e., 1200-1400 LT) peak typically associated with COA, a significant contribution from a wood burning marker $(m / z 60)$ was attributed to HOA. This difficulty in factor separation is likely due to the site location, where the measured aerosol can be influenced by the Bucharest city (in the northern part) or by "cleaner" air masses from surroundings areas. Different type of vegetation like crops and trees (Măgurele forest of approximately 200 ha is located at $1 \mathrm{~km}$ from the site), nearby the measurement site, likely affect the organic spectra profiles. Better results were obtained by dividing the dataset using wind direction as criteria. The summer dataset was divided into two datasets based on the wind directions, one influenced by Bucharest ( $\mathrm{N}$ and NW wind directions) and one influenced by the agricultural area, the nearby forest and other regional influences (the rest of the wind directions). In this configuration, the model provided better solutions, with unmixed factors, comparable with the literature profiles. A four factor configuration was chosen (two secondary-MO-OOA, LO-OOA and two primary-BBOA and HOA) for the regional influenced data, while for the city influenced measurements, a five factor solution was selected, including COA. This is consistent with previous studies where COA is clearly resolved in urban aerosols, but is greatly reduced or absent in rural environments [74].

For the winter dataset, factors deconvolution was based on a different model configuration. Some rough inspection of the data was made on specific markers as $m / z 60,73,55,57$ to assess the biomass burning, cooking or hydrocarbon organic aerosols influence [73]. The model was setup with three to twenty factors (without constraining factors) and a clear separation between POA and SOA 
was observed. Also, sensitivity tests for HOA, COA, coal combustion OA (CCOA), BBOA were made with a step of $a=0.05$, using the literature spectra [12]. The linear combination of factors and time series of organic aerosols during wintertime emphasized the presence of factors related mainly to sources local aerosols.

\section{Results and Discussion}

During the campaigns, the total NR-PM $\mathrm{PM}_{1}$ was significantly higher in winter than summer for all measured species. Mean summer concentrations were $1.7 \mu \mathrm{g} / \mathrm{m}^{3}\left( \pm 1.2 \mu \mathrm{g} / \mathrm{m}^{3}\right) \mathrm{OA}, 0.8 \mu \mathrm{g} / \mathrm{m}^{3}$ $\left( \pm 0.7 \mu \mathrm{g} / \mathrm{m}^{3}\right)$ sulfate, $0.4 \mu \mathrm{g} / \mathrm{m}^{3}\left( \pm 0.3 \mu \mathrm{g} / \mathrm{m}^{3}\right)$ ammonium, $0.2 \mu \mathrm{g} / \mathrm{m}^{3}\left( \pm 0.2 \mu \mathrm{g} / \mathrm{m}^{3}\right)$ nitrate, and $0.1 \mu \mathrm{g} / \mathrm{m}^{3}\left( \pm 0.1 \mu \mathrm{g} / \mathrm{m}^{3}\right)$ chloride. Winter mean concentrations were typically at least three times higher with $7.0 \mu \mathrm{g} / \mathrm{m}^{3}\left( \pm 6.3 \mu \mathrm{g} / \mathrm{m}^{3}\right)$ OA, $1.9 \mu \mathrm{g} / \mathrm{m}^{3}\left( \pm 1.6 \mu \mathrm{g} / \mathrm{m}^{3}\right)$ sulfate, $1.9 \mu \mathrm{g} / \mathrm{m}^{3}\left( \pm 1.2 \mu \mathrm{g} / \mathrm{m}^{3}\right)$ ammonium, $2.5 \mu \mathrm{g} / \mathrm{m}^{3}\left( \pm 1.9 \mu \mathrm{g} / \mathrm{m}^{3}\right)$ nitrate, and $0.1 \mu \mathrm{g} / \mathrm{m}^{3}\left( \pm 0.2 \mu \mathrm{g} / \mathrm{m}^{3}\right)$ chloride. In addition, in winter concentration of NR-PM $\mathrm{PM}_{1}$ exceeded $50 \mu \mathrm{g} / \mathrm{m}^{3}$ during periods dominated by organics. At the beginning of the summer campaign, a high sulfate episode was observed which is discussed in details below.

\subsection{Seasonal Distribution of $N R-P M_{1}$ Species Concentrations}

During the summer measurement campaign, organics represented $53 \%$ of the total NR-PM $\mathrm{PM}_{1}$, followed by sulfate (26\%) and ammonium (14\%). Concentrations of nitrate and chloride were $6 \%$ and $1 \%$, respectively (Figure 1). Total submicron non-refractory aerosol loadings ranged between $2-16 \mu \mathrm{g} / \mathrm{m}^{3}$, with a average concentration of $2.8 \mu \mathrm{g} / \mathrm{m}^{3}$ (Figure 2a). The higher concentrations during summer corresponded to wind speed less than $4 \mathrm{~m} / \mathrm{s}$ and temperatures above $30^{\circ} \mathrm{C}$. Days with higher turbulence and temperatures were characterized by lower concentrations (Figure S1a in the Supplementary Material).

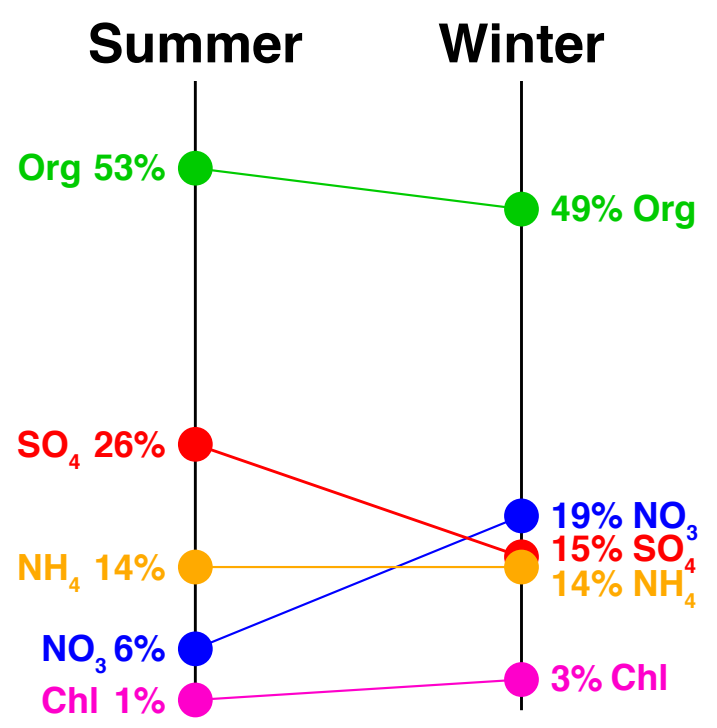

Figure 1. Slopegraph showing the seasonal variation of non-refractory $\mathrm{PM}_{1}$ aerosol $\left(\mathrm{NR}-\mathrm{PM}_{1}\right)$ species.

During the winter campaign, NR- $\mathrm{PM}_{1}$ mass concentrations were higher than in summertime, with an average of $12.4 \mu \mathrm{g} / \mathrm{m}^{3}$ (Figure $2 \mathrm{~b}$ ). About half of the mass loading in winter comes from organics $(49 \%)$, with significant amounts of nitrate $(19 \%)$, ammonium $(14 \%)$ and sulfate $(15 \%)$ (Figure 1$)$, being similar in percentage distribution to that reported reported for other sites (i.e., Paris, Zurich) (e.g., [12,75]). Chloride concentrations were typically less than $3 \%$ of the total mass. An increase in chloride percentage in winter suggests the presence of combustion sources in a proportion higher 
than in summer (Figure 1). An increased proportion of nitrate fraction can be noticed during winter, this fraction being associated with combustion processes including solid fossil fuel [39].
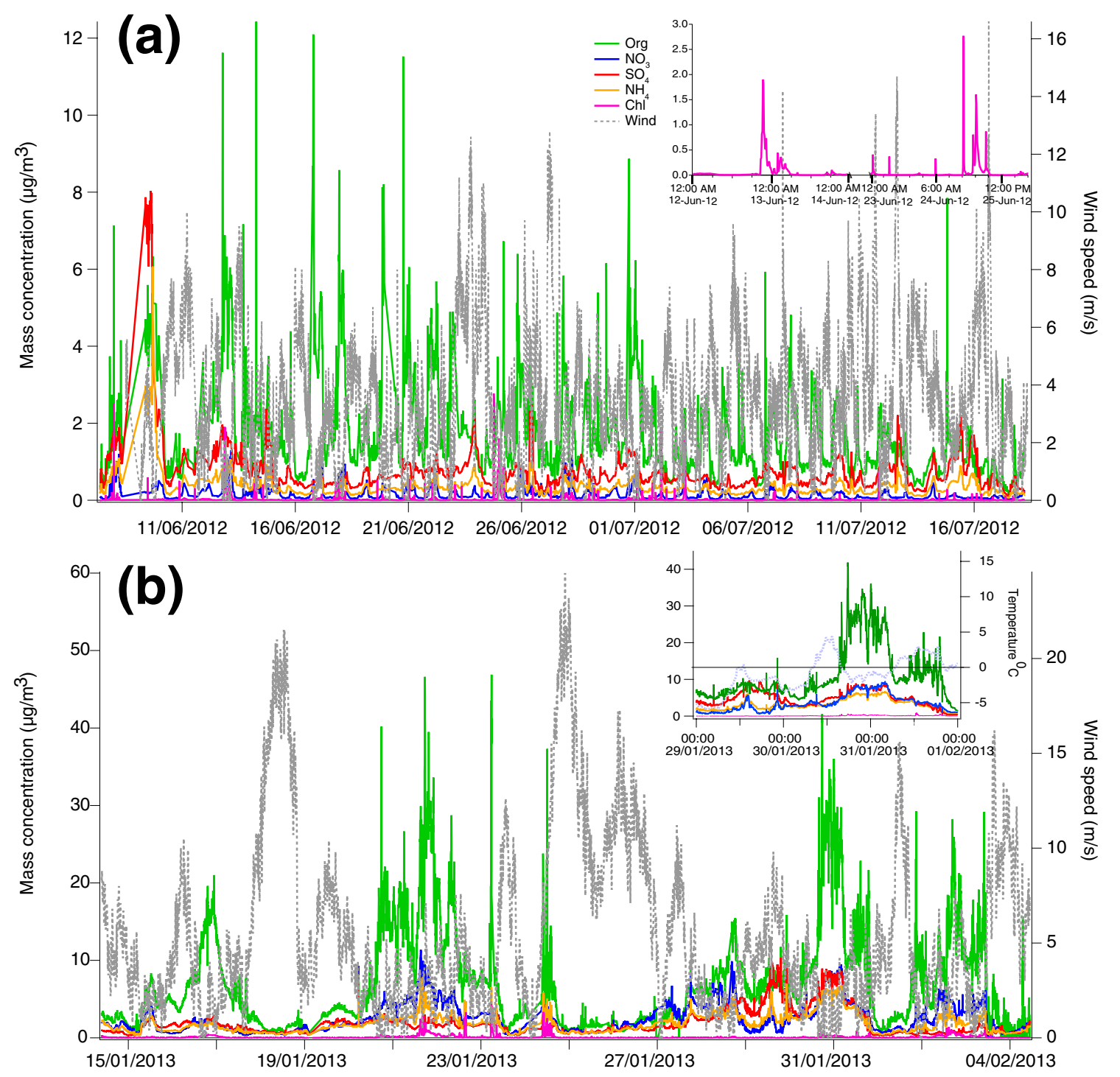

Figure 2. Mass loadings of aerosol species measured in Romania: (a) summer; (b) winter. Green-organic (Org), blue-nitrate $\left(\mathrm{NO}_{3}\right)$, red-sulfate $\left(\mathrm{SO}_{4}\right)$, yellow-ammonium $\left(\mathrm{NH}_{4}\right)$, pink-chloride (Chl) fractions; grey dotted line-wind speed. In (a) a zoom of chloride variation is presented for the summer period. In (b) a zoom of fractions variation is presented for the winter period together with temperature variation.

The wintertime campaign was characterized by periods of wind reaching a maximum of $25 \mathrm{~m} / \mathrm{s}$, that corresponds to low chemical components loadings, and temperature ranging from -7 to $17^{\circ} \mathrm{C}$. Higher concentrations of submicronic non-refractory aerosols were noticed when temperatures decreased below $0{ }^{\circ} \mathrm{C}$ (Figure S1b in the Supplementary Material), due to combustion activities that heavily influence the total $\mathrm{PM}_{1}$ loading (see Section 3.3.3).

At the beginning of the summer campaign higher sulfate concentrations were recorded between 7-10 June 2012, reaching approximately $8 \mu \mathrm{g} / \mathrm{m}^{3}$, three times higher than values recorded during the rest of the campaign (Figure $2 \mathrm{a}$ ). Higher concentrations were related to wind from $\mathrm{S}, \mathrm{E}$, and SE with an average of $2 \mathrm{~m} / \mathrm{s}$ and peaks up to $8 \mathrm{~m} / \mathrm{s}$. The enhancement of sulphate during this period can be 
associated with long-range transport, with an increase in concentrations of OOA (see Section 3.3.2) being recorded as well.

A few events with high chloride concentrations were also recorded during the summer measurements. In all cases, spikes in chloride correlated with spikes in ammonium, suggesting that the chloride occurs in the form of ammonium chloride. We speculate that the high chloride concentration is due to long-range transport, local sources, and uncontrolled fires. The long-range transport of chloride can be associated with marine aerosols, but just under special atmospheric conditions (e.g., rapid air masses circulation), Black Sea being situated at approximately $300 \mathrm{~km}$ east from Măgurele. As indicated in the previous studies, particulate-phase chloride (e.g., $\mathrm{NaCl}, \mathrm{KCl}$ ) react with $\mathrm{H}_{2} \mathrm{SO}_{4}$ or $\mathrm{HNO}_{3}$ (or with both of them) to release gas-phase $\mathrm{HCl}$. This will further produce $\mathrm{NH}_{4} \mathrm{Cl}$ when reacting with $\mathrm{NH}_{3}$ or chloride-dust (which cannot be detected through the methods used in this article) when reacting with dust [76]. The chemical processes that intervene in sodium chloride transformation depend on the presence of $\mathrm{HNO}_{3}$ (originating from transformation of traffic and industrial $\mathrm{NO}_{x}$ emissions) and $\mathrm{NH}_{3}$ (agricultural activities being the most common source). SIA (secondary inorganic aerosols), such as ammonium chloride, formed in the presence of hydrochloric acids and ammonia are more stable in the atmosphere up to few days and the aerosols can be transported far away from original sources [77]. According to HYSPLIT [62] back trajectories, one case of high chloride concentrations greater than $0.5 \mu \mathrm{g} / \mathrm{m}^{3}$ corresponds to air masses coming from the Black Sea area (12-13 June 2012, Figure S2 in the Supplementary Material). All other cases considered, with concentrations higher than $0.5 \mu \mathrm{g} / \mathrm{m}^{3}$, were not linked with air masses with origin over the Black Sea.

The presence of important sources, located nearby, such as local industry, coal, biomass or agricultural waste burning can be responsible for high chloride concentrations. Because the event occurred during the summer, we can exclude coal combustion. The chloride is not associated with industrial sources because $\mathrm{Chl}$ fraction is usually less than $1 \%$ over the year [25], with no clear patterns recorded. Because ammonium chloride is also used as a fertilizer, the agricultural area surrounding the Măgurele site is most likely the source of ammonium and also chloride. The burning process of agriculture waste releases into the atmosphere $\mathrm{HCl}$ and $\mathrm{NH}_{3}$, through thermal decomposition [78]. The highest concentration of $2.76 \mu \mathrm{g} / \mathrm{m}^{3}$ was measured on $24 \mathrm{June}$, anionic species dominating the aerosol concentration. During the time period with enhancement in chloride concentration the presence of acidic aerosols is underlined. Based on MODIS fire detection maps, on 24 June 2012 no significant fire was detected over Romania. For this particular case, the high concentrations of chloride were most likely caused by small agricultural waste fires, from areas close to the measurement site.

Important loadings of biomass burning aerosols with different origins have been observed during summer. Local and regional sources of organic aerosols are associated with agricultural activities and with significant vegetation fires across Europe [79-81]. Stubble burning, used by farmers to clear crop residues from the land, during the summer represents the main local emission source, having a high incidence in agricultural areas in Romania. During 2012, there were approximately 500 interventions by firefighters for uncontrolled stubble fires in the Măgurele area, with higher incidence during June-August compared with rest of the year [82].

Several episodes with high organic concentration $\left(>30 \mu \mathrm{g} / \mathrm{m}^{3}\right)$ were observed during winter. One of those being highlighted in the right panel of Figure $2 b$. These episodes occurred during periods characterized by calm wind conditions and are likely due to domestic heating, which represents one of the major source of aerosols at the site (see Section 3.3.3). Also, during the campaigns the ratio between organics to inorganics aerosol was almost 1, with one exception (i.e., 26-30 January) when inorganics dominated NR-PM 1 fraction (average 0.68).

Higher aerosol mass concentrations are observed in winter than in summer. High concentrations were recorded on 21, 28, 31 January and 1-4 February 2013. Organic concentrations up to $47 \mu \mathrm{g} / \mathrm{m}^{3}$ where recorded for short periods being related with high increases in $\mathrm{SO}_{4}$ concentrations of around $10 \mu \mathrm{g} / \mathrm{m}^{3}$ and also $\mathrm{NO}_{3}$ around $5 \mu \mathrm{g} / \mathrm{m}^{3}$ (Figure $2 \mathrm{~b}$ ). These periods are characterized by temperatures below $0{ }^{\circ} \mathrm{C}$ and are associated with residential heating processes. Wood and fossil fuels are the 
main combustion sources used for the residential heating, therefore highly contributing to the $\mathrm{PM}_{1}$ concentrations.

Meteorological parameters such as temperature and wind also have an essential influence on aerosol loading [83]. Pollution caused by industrial activities and the heating practices is enhanced when temperatures are below $0{ }^{\circ} \mathrm{C}$ and wind is characterized by calm conditions. Thus, high concentrations of NR-PM 1 were observed on 21, 28, 31 of January and 1-4 February. The aerosol organic aging process and their separation into primary organic aerosols and oxygenated organic aerosols were analyzed using the ratio $f 43$ versus $f 44$ (Figure $3 a$ ). More oxygenated aerosols associated with carboxylic groups, highlighted by $f 44$ high values, were observed on 15 and 26-29 January 2013.

The $f 44$ versus $f 60$, the marker for levoglucosan, indicates the presence of biomass burning organic aerosols and low volatility oxygenated organic aerosols (Figure $3 b$ ). At the end of January and beginning of February, higher $f 60$ and lower $f 44$ values were recored, indicating more fresh aerosols. For more than $99 \%$ of the measurements the $f 60$ exceeded the background value (0.003) [84], consistent with the presence of biomass burning as main POA source in this area.

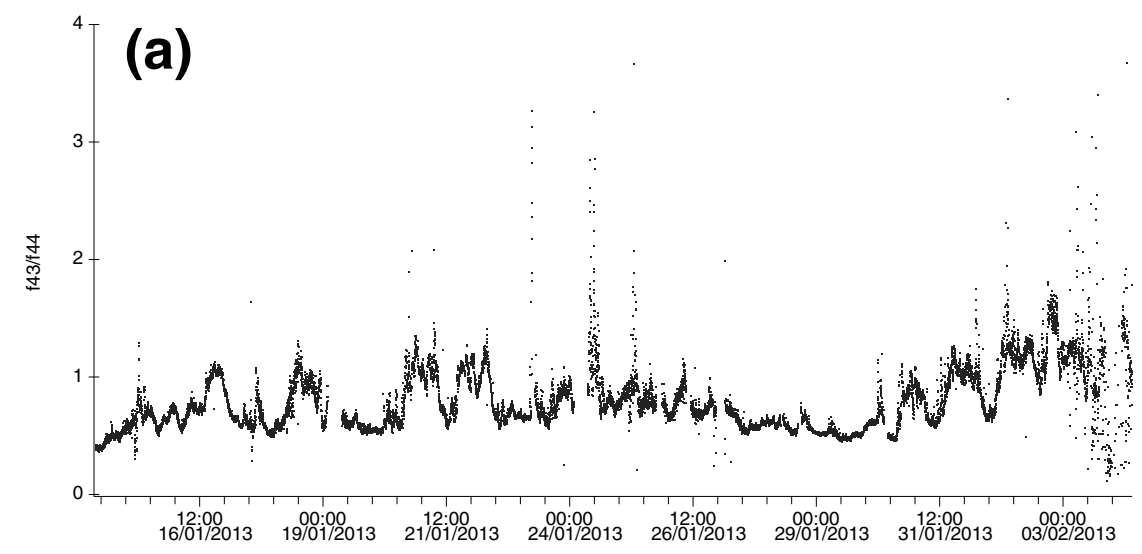

(b)

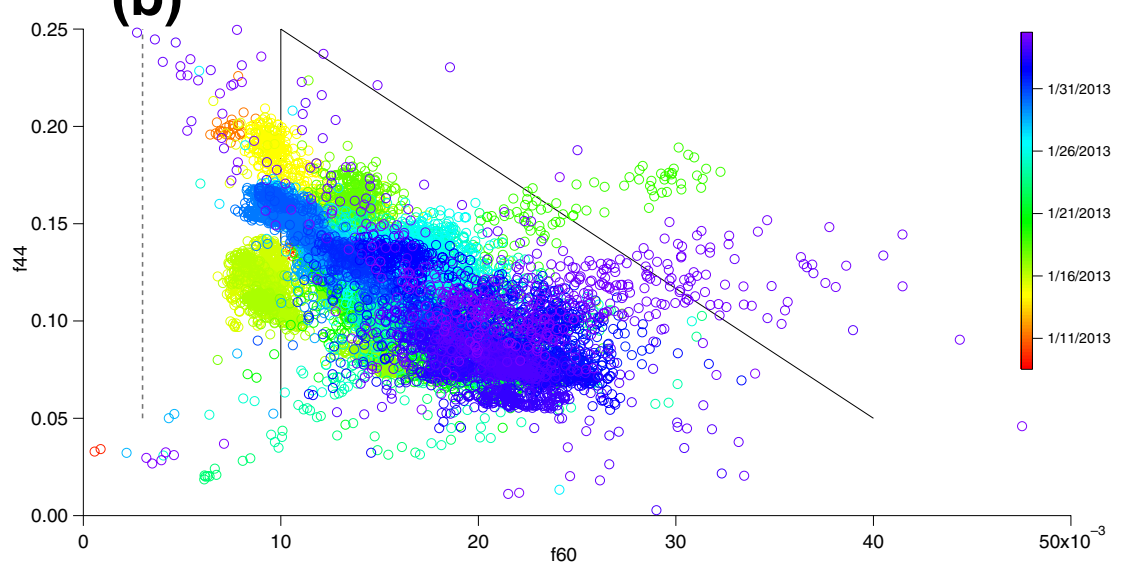

Figure 3. Winter (a) f43/f44 ratio time series; (b) f44 versus $\mathrm{f} 60$ colored by date (vertical dashed black line represents the $\mathrm{f} 60$ background level of 0.003 ; black lines represents the ambient biomass burning organic aerosol (BBOA)-related data space introduced by Cubison et al. [84].

Submicron aerosol size distributions during summer is characterized by a mean diameter of $500 \mathrm{~nm}$ for all organics and inorganic fractions, while in the winter the aerodynamic vacuum diameter is lower, ranging from $350-500 \mathrm{~nm}$, characteristic for accumulation mode. The main local sources in the sampling site area are related to traffic all over the year, and residential heating during the cold season. Because the residential heating source is an important contributor to local PM 
concentrations during winter (Figure $4 \mathrm{~b}$ ), it is expected that source to influence the size distribution pattern. Unlike organics, inorganic fractions of ammonium and nitrate are centered at 500-600 $\mathrm{nm}$ for both seasons, while sulphate is centred on $500 \mathrm{~nm}$ in summer and on approximate $600 \mathrm{~nm}$ in winter (Figure $4 \mathrm{~b}$ ). The chloride fraction is negligible during summer and present during winter being centred on $400 \mathrm{~nm}$, and related with residential heating processes.
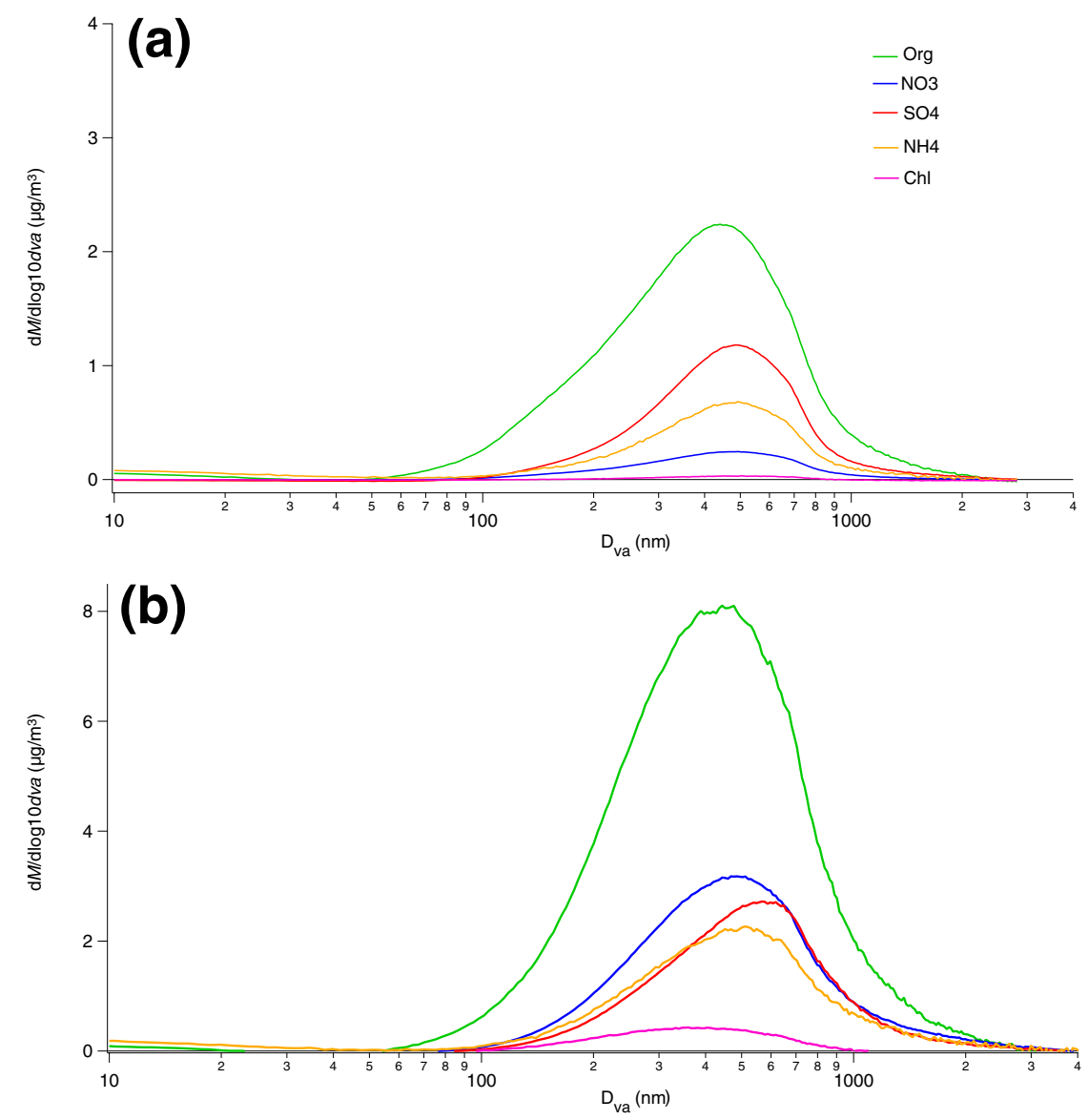

Figure 4. Average mass size distributions (dM/dlog $10 \mathrm{D}_{v a}$ ) of ammonium (yellow), nitrate (blue), sulfate (red), chloride (pink) and organics (green) (a) summer; (b) winter. $\mathrm{D}_{v a}$ represents the vacuum aerodynamic diameter.

The presence of different sources, depending on the season, is visible in a diurnal pattern of each chemical fraction. In Figure 5a the diurnal hourly mean concentrations during summer of inorganic species and total organics are plotted for weekdays and weekends. Most chemical fractions exhibit a flat diurnal pattern, with the exception of nitrate and organics, that have a more pronounced diurnal variation with lower concentrations during the day time. The main source of organics and nitrate are daily activities (e.g., traffic), while sulfate is usually associated with long-range transport and ammonia with agricultural practices that do not have a daily pattern. The dilution effect of PBL height can have an important influence in summer, thus the day-time concentration of the pollutants is lower. For organics, this trend is more pronounced on weekdays than the weekend. Increased concentrations of nitrate and sulfate for the weekend are associated with the increased pollution episode of these compounds from the beginning of the campaign, recorded Saturday and Sunday. 

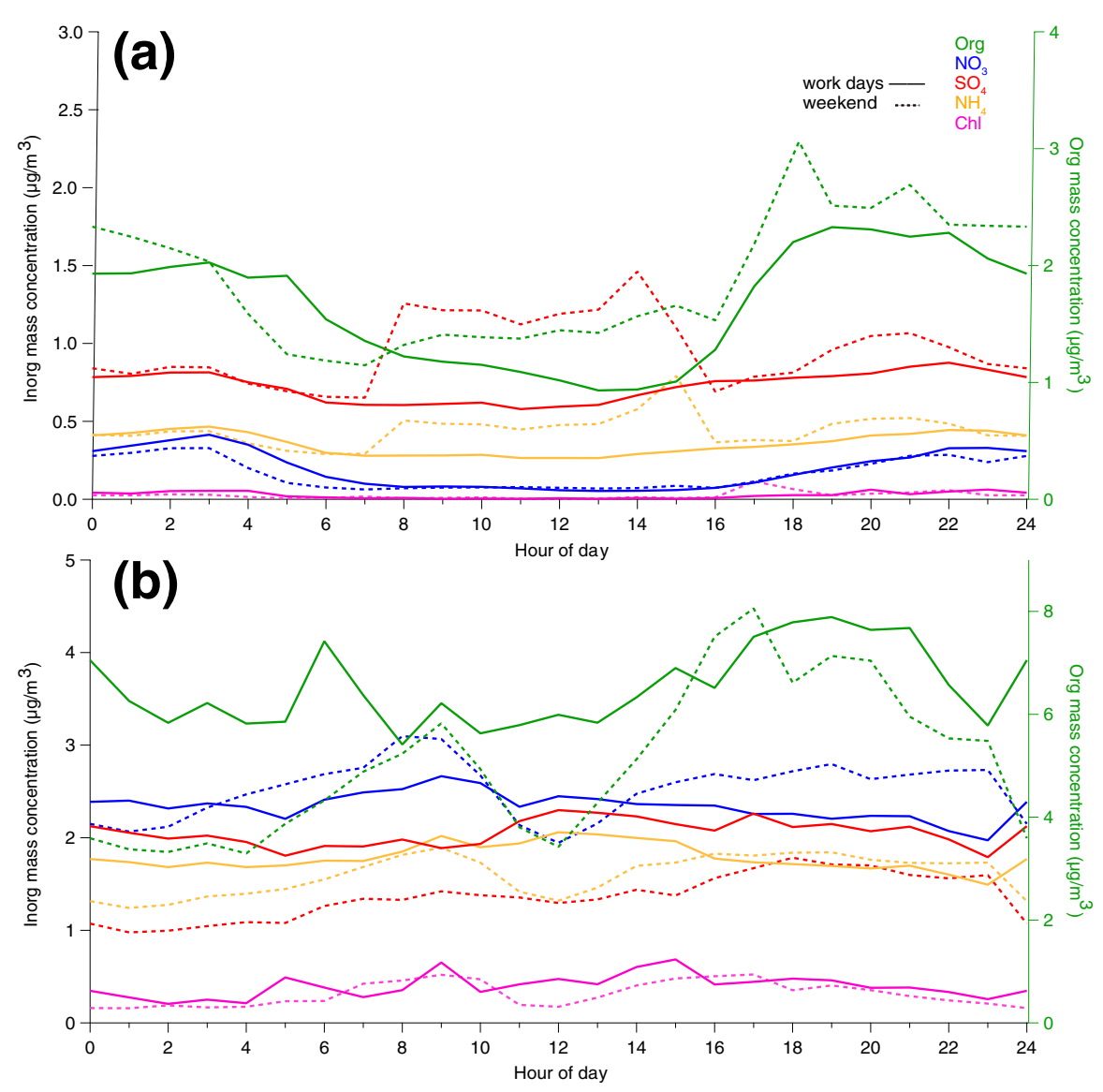

Figure 5. Diurnal pattern of chemical species during work days (regular lines) and weekends (dashed lines): (a) summer; (b) winter. Green-organic (Org), blue—nitrate $\left(\mathrm{NO}_{3}\right)$, red-sulfate $\left(\mathrm{SO}_{4}\right)$, yellow-ammonium $\left(\mathrm{NH}_{4}\right)$, pink-chloride $(\mathrm{Chl})$ species.

Figure $5 \mathrm{~b}$ shows the diurnal patterns of NR-PM 1 species, divided into weekdays and weekends during wintertime. The inorganic species are less influenced by the diurnal cycle driven by, for example, the intensity of sources during the day (i.e., wood burning including smoldering phase), the production (i.e., gas to particle conversion), depletion (i.e., particle to gas conversion) of pollutants and dilution processes (i.e., planetary boundary layer height fluctuation). The organic fraction presents a low diurnal pattern that is related to traffic and residential heating activity. On weekends, the diurnal variation is clearly observed for nitrate and ammonium, higher concentrations of these species being observed in the morning and afternoon, related to the $\mathrm{NO}_{x}$ availability from ring road traffic close to the measurement site. The weekends nitrate diurnal pattern can be associated with gas-particle partitioning. This is influenced by temperature variations, higher concentration levels during the night time, and decreasing loadings related to increasing temperature during morning (Figure $5 b$ ). These findings are in accordance with the Paris measurements [12]. The diurnal pattern of inorganic and organic species highlights new particle formation derived by photochemical oxidation. The high winter nitrate concentrations show the influence of anthropogenic emissions due to the proximity of downtown Bucharest. The fractional contribution of nitrate to non-refractory $\mathrm{PM}_{1}$ aerosol $(19 \%)$ is typical for a high polluted site accordingly to previous studies (e.g., [13,75]).

Higher concentrations for chloride were recorded during winter, being often associated with combustion sources [85], like coal or biomass burning [86,87]. This indicates a higher contribution of chloride fraction to local pollution during winter compared with summer. Several peaks are visible in the chloride diurnal pattern that can be related with biomass burning. The peaks around 05:00 
and 09:00 A.M. local time are evidenced in the diurnal cycle of BBOA (Figure 5b and Figure 9c) that indicate the residential heating origin as main source.

\subsection{Vertical Distribution and In Situ Concentration of Aerosols}

An intensive measurements campaign was conducted from 9-11 July 2012. During the campaign, lidar measurements were made continuously for 72-h and are discussed below together with aerosol loading at ground level to understand possible regional influences. From the lidar measurements, information about the vertical distribution of aerosol and temporal dynamics of the PBL were extracted. The aerosol layers emphasized the presence of particles with different origins. Thus, the upper layers at around $4000 \mathrm{~m}$ were related with long-range transport. The Hysplit trajectory model indicated that the site was influenced mainly by air masses coming from western and southern Europe (Figure S3 in the supplementary material). The layers below the PBL height were highly influenced by local sources of primary aerosols and also by physical and chemical processes that lead to formation of secondary aerosols (Figure S4 in the supplementary material). This corresponds to urban pollution but also, as indicated by MODIS data, to aerosols from vegetation fires over southern Romania (Figure S5 in the supplementary material). The PBL (Figure S6 in supplementary material) was dynamic, reaching during the day altitudes of approximately $2500 \mathrm{~m}$ and descending during nights to below $700 \mathrm{~m}$, or sometimes even lower than the lidar system overlap.

The PBL height and temperature variations influence the total submicron aerosol concentration, which is approximately $2 \mu \mathrm{g} / \mathrm{m}^{3}$ higher during the night than during the day. Figure 6 shows a sample time series of organics, nitrate, sulfate, ammonium, and chloride between 9-13 July 2012, together with the computed PBL height, derived from LIDAR measurements. A clear diurnal pattern is pointed out for organics and nitrates that is anticorrelated with the PBL and temperature variation. The PBL height increases dilute the NR-PM 1 at the ground level, while PBL drops during the night time concentrate the pollutants. Increased loadings of aerosol at the ground level during the night are related to lower PBL height. The turbulent exchange within mixing layers, especially during the day, determines the mix of long-range transported aerosols with the local one (Figure S6 in supplementary material) as shown, for example, by Nicolae et al. [26]. From the aerosol vertical profiles we can determine the presence of layers at approximately $4000 \mathrm{~m}$ altitude from 9-11 July 2012 at 02:00 A.M. local time, above the top of the PBL, as evidenced by Dandocsi et al. [55].

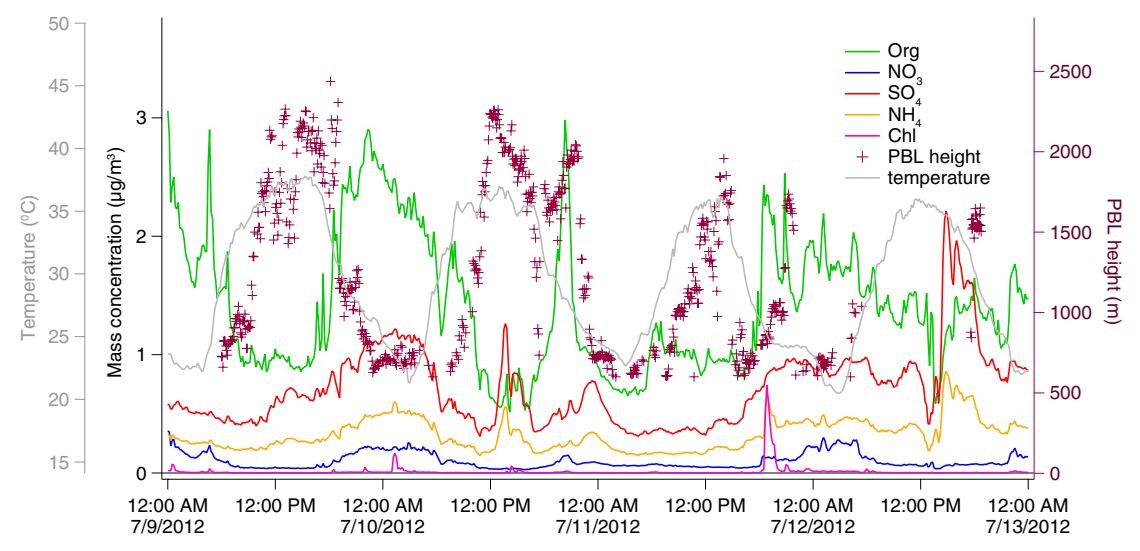

Figure 6. Temporal evolution of planetary boundary layer (PBL) height (red crosses), overlaid temperature fluctuation (grey line) and in situ $\mathrm{PM}_{1}$ species concentration: green-organic (Org), blue-nitrate $\left(\mathrm{NO}_{3}\right)$, red—sulfate $\left(\mathrm{SO}_{4}\right)$, yellow—ammonium $\left(\mathrm{NH}_{4}\right)$, pink—chloride $(\mathrm{Chl})$.

At the ground base level, anhydride sugars such as levoglucosan yield characteristic fragments at $m / z 60$ and 73. These $m / z$ are present in high concentrations above typical background levels estimated by Cubison et al. (0.003) [84]. Double the background level $f 60$ values were observed 
between 11-13 July 2012, when Hysplit back-trajectories indicated air masses advected from western Europe and Balkans; during the same period MODIS fire map revealed a high density of vegetation fires, as also discussed by Samaras et al. [81]. The separation between these two possible influences, long-range and local transport, cannot be done. The level of oxidation of organic particles and the reduced life time in the air of levoglucosan marker might underline the presence of local sources more than sources attributed to long-range transport.

Wintertime Lidar measurements show that the PBL height fluctuates from less than a few hundred meters during night (i.e., below the Lidar overlap) to a maximum of $1000 \mathrm{~m}$ at noon (Figure S7 in supplementary material). The PBL evolution during cold season at Măgurele is in accordance with the findings of Matthias et al. regarding the minimum average height specific for this latitude at the beginning of January [88]. The PBL variation between day and night is lower than in summer, reaching values of $1000 \mathrm{~m}$ during the day and decreasing below $500 \mathrm{~m}$ at night. These low boundary layers reduce vertical mixing and thus dilution, contributing to the higher aerosol concentrations in winter. The PBL height during 23th of January (marked with white crosses in Figure S7 in supplementary material) shows a clear stratification of layers. During the winter, convection processes are not strong enough due to low temperature variations. Due to this, pollutant concentration are not high influenced by dilutions processes. This contrasts with the higher fluctuations in PBL heights for summer as shown above, where the mixing height increases from $500 \mathrm{~m}$ at night to $2500 \mathrm{~m}$ at noon.

\subsection{Source Apportionment}

Source apportionment results indicate several types of primary organic aerosols, biomass burning organic aerosols-influenced by both local agricultural activities and distant vegetation fires, hydrocarbon-like organic aerosols-related to traffic activity and influenced by the ring road of Bucharest, and cooking-related organic aerosol. Two secondary oxygenated organic aerosol factors were also resolved. The organic mass spectra separation is based on the characteristics of each factor. HOA have peaks related with long saturated and unsaturated hydrocarbon chains, as $m / z 41\left(\mathrm{C}_{3} \mathrm{H}_{5}^{+}\right)$, $m / z 43\left(\mathrm{C}_{3} \mathrm{H}_{7}^{+}\right), m / z 55\left(\mathrm{C}_{4} \mathrm{H}_{7}^{+}\right), m / z 57\left(\mathrm{C}_{4} \mathrm{H}_{9}^{+}\right), m / z 67\left(\mathrm{C}_{5} \mathrm{H}_{7}^{+}\right), m / z 69\left(\mathrm{C}_{5} \mathrm{H}_{9}^{+}\right), m / z 71\left(\mathrm{C}_{5} \mathrm{H}_{1} 1^{+}\right)$, $m / z 79\left(\mathrm{C}_{6} \mathrm{H}_{7}^{+}\right), m / z 81\left(\mathrm{C}_{6} \mathrm{H}_{9}^{+}\right)$and $m / z 83\left(\mathrm{C}_{6} \mathrm{H}_{11}^{+}\right)$(e.g., [72,89,90]). BBOA is described by higher contributions to $m / z 60\left(\mathrm{C}_{2} \mathrm{H}_{4} \mathrm{O}_{2}^{+}\right)$and $m / z 73\left(\mathrm{C}_{3} \mathrm{H}_{5} \mathrm{O}_{2}^{+}\right)$, which are characteristic ions of anhydro sugars such as levoglucosane derived from cellulose pyrolysis [84]. COA is similar with $\mathrm{HOA}$ in terms of the $m / z$ with the highest signal $(m / z 41,43,55,57)$, but the ratios of $m / z 41 / 43$ and $55 / 57$ ratio are higher in COA than HOA. Also, a peak during the meal hours in the diurnal pattern indicates the presence of COA factor [18].

For both seasons, the factor separations approaches were similar. The summer dataset was split in two separate time series, to describe in more details the local influences. Analysis of the entire summer dataset show that COA and HOA cannot be fully separated. This is likely due to local meteorological influences, specifically wind direction and the proximity of the site to Bucharest city. As a result, PMF analyses were conducted on two distinct datasets (i) N/NW wind sectors (from the city, analyzed in section refcity) and (ii) the rest wind sectors (regional, analyzed in section refregional). For the city influence, five factors were evidenced including COA that represent the reason for organic time series splitting approach, while for the regional influence one solution with four factors was found, with no clear evidence of COA. The presence of mixed aerosol sources is due to the presence of two main wind directions influenced by local topography, i.e., south of the Carpathian Mountain. Thus, the frequency of the wind direction is distributed as following: more than $20 \%$ in the warm season is dominated by wind from the NE and more than 15\% from SW [91].

\subsubsection{City Influence during Summer}

For the city dataset during summer, five factors were identified in Măgurele: BBOA, COA, HOA, MO-OOA, and LO-OOA. To facilitate the separation of HOA and COA, HOA was constrained using 
a reference spectrum from Paris with $a$-value of 0.1 [12]. Sensitivity tests have been performed for all POA spectra that were used to constrain the PMF solutions. Thus, the $a$-values was varied between 0.05-0.5. Screening of residual plots, as well as the correlations of SOA factors with $\mathrm{SO}_{4} \mathrm{Or}^{\mathrm{NO}_{3}}$, have been investigated. The relative proportions on pairs of variables $(\mathrm{m} / \mathrm{z} 41$ and 43,43 and 44,55 and 57,69 and 71) were taken into account for each solution to choose the appropriate HOA or COA spectra. BBOA factor and different $a$-values were tested. A higher constrain, with low $a$ values, resulted in a significant fraction of BBOA specific tracers, distributed to HOA or OOA factors. The best results were obtained with an $a$-value of 0.5 . A constrained $a$-value of 0.3 was used for COA, after a sensitivity test for this source with steps of 0.05 . For this factor the $m / z 41 / 43$ and 55/57 ratios were considered together with peak between 12:00-14:00 local time (i.e., meal peak) (Figure 7). One factor identified was HOA, that is an outcome of vehicle exhaust. HOA shows a diurnal pattern related to the proximity of the ring road and traffic activity, with peaks around 06:00 A.M. local time (i.e., rush hour) and 11:00 A.M. local time (i.e., high traffic flow due to increased traffic on Bucharest ring road) (Figure 7c). MO-OOA presents a rather flat diurnal pattern due to regional sources [92], while LO-OOA follows the temperature and planetary boundary layer variation.

The distinct peaks of $m / z 60$ and $m / z 73$ were attributed to BBOA factor. Laboratory tests made under typical atmospheric conditions, indicated a lifetime for levoglucosan from $15 \mathrm{~h}$ to few days [93], the aging process being evidenced by $f 44 / f 60$ ratio [84]. In this case, the last period of the campaign is characterized by more aged $\mathrm{OA}, f 44$ reaching values of approximately 0.2 .

Another factor identified, just for the city influence, is COA that has a peak between 12:00-14:00 P.M. local time that is related to the meal hours. The $m / z 41 / 43$ and $55 / 57$ ratios have values of 2.16 and 2.28, respectively higher than in the case of HOA, 0.99 and 1.03, respectively. The COA contribution to the total OA was $\sim 13 \%$, higher than $\mathrm{HOA} \sim 10 \%$ and similar to BBOA $~ 13 \%$.

Two oxidized organic aerosols patterns were identified, less oxygenated organic aerosols and more oxygenated organic aerosols. MO-OOA is better correlated with sulfate originating from regional sources. The SOA represent the predominant fraction, contributing $63 \%$ to the total OA concentration. Duringthe first (9-10 June) and last part (9-18 July) of the campaign, SOA concentration $\left(1.789 \mu \mathrm{g} / \mathrm{m}^{3}\right.$ and $\left.1.02 \mu \mathrm{g} / \mathrm{m}^{3}\right)$ exceeds POA $\left(0.768 \mu \mathrm{g} / \mathrm{m}^{3}\right.$ and $\left.0.46 \mu \mathrm{g} / \mathrm{m}^{3}\right)$ by more than two times, highlighting the periods with higher oxidation degree of OA. Both POA and SOA present a diurnal variation following the temperature, but a higher influence can be observed in the variation of POA concentration (Figure S8 in Supplementary Material).

\subsubsection{Regional Influence during Summer}

The regional influence data set was analyzed selecting the cases when the wind direction was from agricultural area and from the nearby forest, excluding wind directions that passed over Bucharest and its surrounding urban regions. Similar to the city-influenced data, BBOA, HOA, MO-OOA, and LO-OOA were resolved. Comparable approaches have been used to identify the best factors to characterize the regional influence. Sensitivity test have been done for all primary factors, using successive $a$-values ranging between $0.05-0.5$. Several combinations of spectra constrains were applied, but in this case the COA spectra has not been identified. The HOA was constrained with $a=0.4$ and BBOA with $a=0.2$ (using for both Paris spectra) [12] (Figure 8). A small increase in HOA concentration is observed in the diurnal variation starting with 07:00 A.M. when traffic activities increase. The general trend of HOA concentration decrease as the PBL height rises and the pollutants concentration is diluted. 

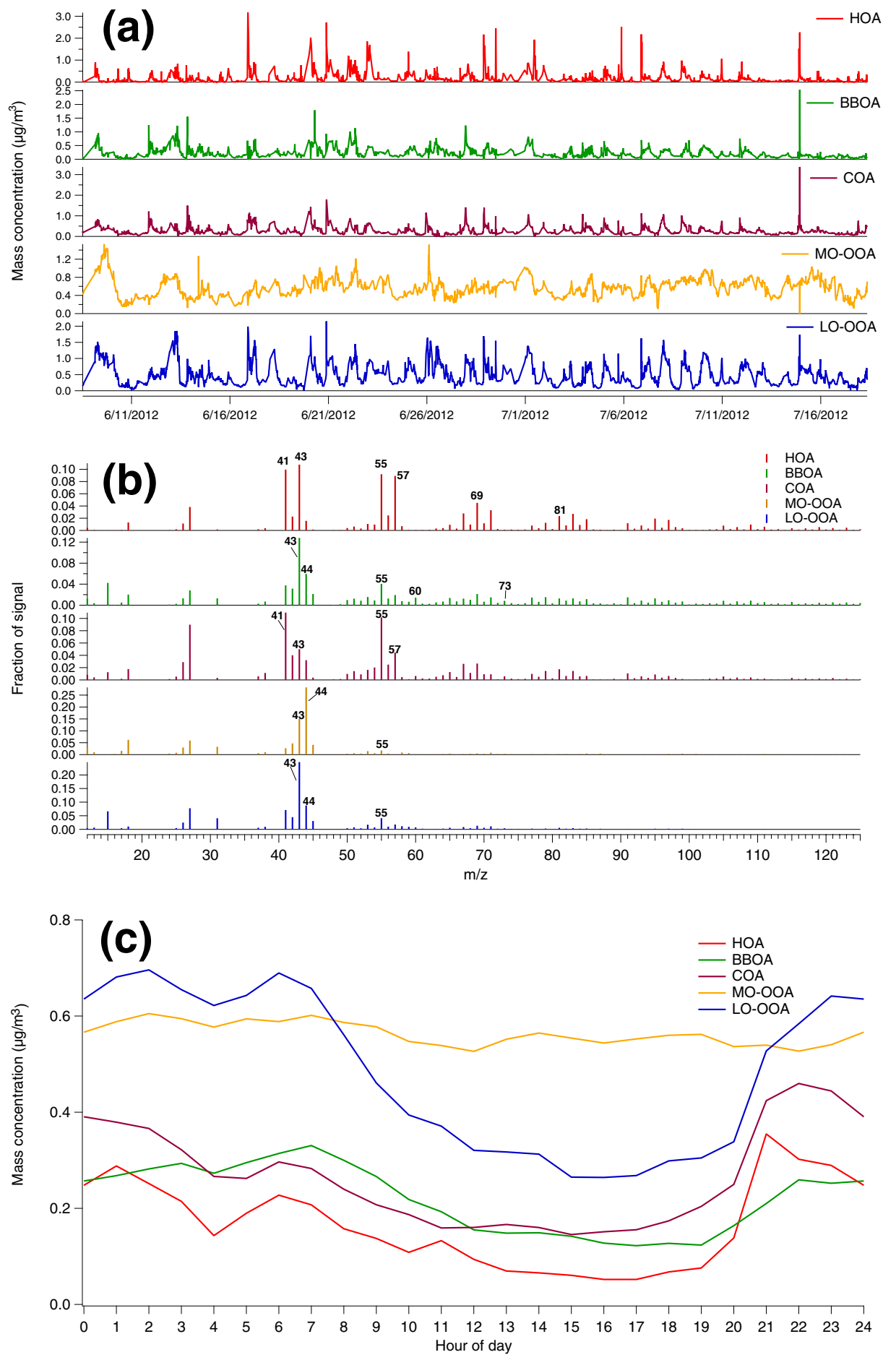

Figure 7. Positive matrix factorization result for city influence during summer: (a) time series of the organic factors, (b) mass spectra of the organic factors, and (c) diurnal variation of the factors. Orange-hydrocarbon-like organic aerosol (HOA), green-BBOA, red-cooking organic aerosol (COA), yellow-more oxygenated oxygenated organic aerosols (MO-OOA), and blue-less oxygenated oxygenated organic aerosols (LO-OOA). 

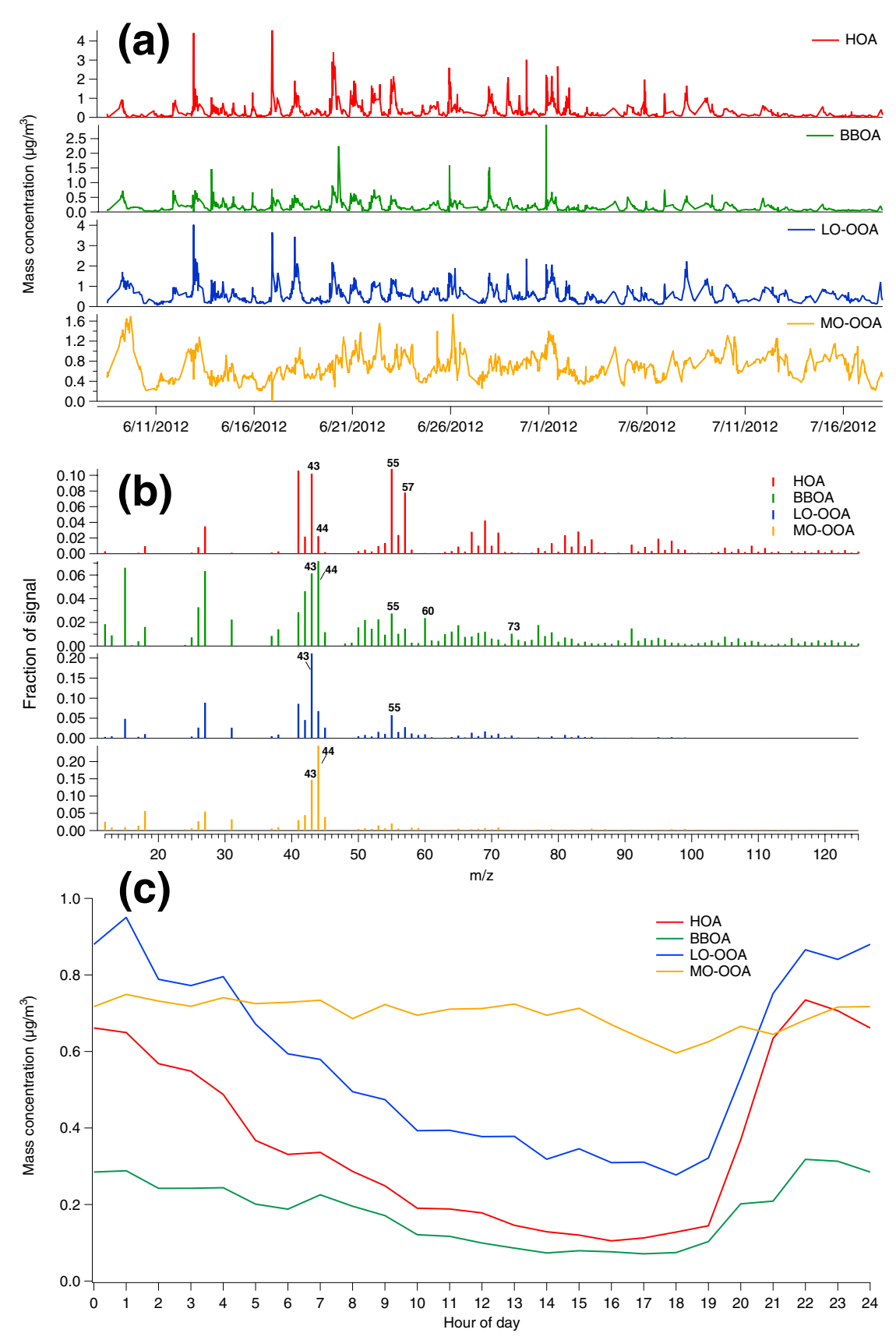

Figure 8. Positive matrix factorization result for regional influence during summer: (a) Time series of the organic factors, (b) Mass spectra of the organic factors, and (c) Diurnal variation of the factors. Orange-HOA, green-BBOA, blue-LO-OOA, and yellow-MO-OOA.

The fraction of the organic mass spectrum at $m / z 44(f 44)$ and $m / z 60(f 60)$ highlights the biomass burning events, as well as the aging process of the aerosols in specific cases [94]. The AMS biomass burning marker showed a significant variability of aerosol properties over the entire campaign. During the aging process, the biomass burning aerosols indicator, the $f 60$, ranged between $0.007-0.009$. The secondary organic aerosols factors (LO-OOA and MO-OOA) identified had a distinct diurnal pattern revealing their different origin, confirmed also by the correlations with inorganic fractions. The time series of LO-OOA (average concentration of $0.56 \mu \mathrm{g} / \mathrm{m}^{3}$ ) correlates with $\mathrm{NO}_{3}\left(\mathrm{r}^{2}=0.67\right.$ ), the diurnal pattern indicating a combination of PBL evolution and temperature-driven partitioning. A higher concentration (average $0.69 \mu \mathrm{g} / \mathrm{m}^{3}$ ) is recorded in the case of MO-OOA that has a more 
regional characteristics, without a pronounced diurnal variation. The MO-OOA factor is better correlated with $\mathrm{SO}_{4}\left(\mathrm{r}^{2}=0.6\right)$ and therefore could be associated with long-range transport (e.g., [95]) (Figure 8 ). The $f 43$ and $f 44$ analysis indicates the increase oxidation state of the organic aerosols (Figure S9 in Supplementary Material). The more oxidized component with regional origin, MO-OOA, is representative up to $36 \%$ of the total OA with high $f 44$ values.

The BBOA spectra contain also more signal at $m / z 44$ that indicate some OOA mixing into this factor. The regional influence and more oxidized compounds can be evidenced by higher proportion of SOA from the total organics. SOA represent the predominant part approximately $72 \%$ to the OA concentration, higher than the city-influenced data (63\%). SOA concentration is usually two times higher than POA, for all regionally influenced data, a slightly higher differences being present at the beginning (9-10 June 2012) and last part (3-18 July 2012) of the campaign. These periods with higher oxidation degree of OA were also identified for the city-influence data (Figure S8 in Supplementary Material). POA and SOA have similar diurnal trends, less pronounced diurnal variation than in the city-influence case, but morning traffic peak is still identifiable on POA diurnal trends (Figure S10 in supplementary material).

\subsubsection{Organic Aerosol Sources during Winter}

Similar to the summer case, the positive matrix factorization approach was applied for up to twenty unconstrained factors, in order to identify the standalone sources. Both primary and secondary organic aerosol sources are identified during winter. In winter, the complete separation was not possible, given the emissions at the same time (e.g., traffic, residential heating). The main sources retrieved were a mixture of BBOA and aerosol from coal combustion (BBOA-CCOA), HOA related to urban aerosols, and oxygenated organic aerosols (OOA) (Figure 9).

Both primary and secondary organic aerosols are present during winter measurements campaign in almost equal proportions. Overall SOA slightly dominates the OA total concentration, having a proportion of $\sim 55 \%$. Only for a short period of time (25-30 January 2013) SOA concentration was two times higher than POA. The SOA diurnal trend shows two small peaks, during the noon and the evening, which are probably associated with photo-oxidation processes and aqueous-phase reactions [96], and in the evening, as a result of the presence of other sources of $\mathrm{OH}$ radicals like heterogeneous HONO [97] (Figure S11 in Supplementary Material).

The BBOA presence was confirmed by correlations between biomass burning time series and $\mathrm{m} / \mathrm{z}$ 60 and 73 ( $\mathrm{r}^{2}$ of 0.66 and 0.69 , respectively). Significant occurrence of PAH in the BBOA raw spectra lead to the investigation of the coal combustion markers present in the organics spectra. The factor profiles that contain PAH signals, suggest a mixture of BBOA with CCOA, or overloaded wood burners (e.g., [98]). This hypothesis must be investigated more in future studies through analyses of combustion practices in this study area. BBOA with CCOA factor contains spectral markers for both wood burning $\left(\mathrm{C}_{2} \mathrm{H}_{4} \mathrm{O}_{2}^{+} m / z 60, \mathrm{C}_{3} \mathrm{H}_{5} \mathrm{O}_{2}^{+} m / z 73, \mathrm{C}_{7} \mathrm{H}_{15} \mathrm{O}_{2}^{+} m / z 115, \mathrm{C}_{10} \mathrm{H}_{8}^{+} \mathrm{m} / z\right.$ 128), and coal combustion $\left(\mathrm{C}_{7} \mathrm{H}_{15} \mathrm{O}^{+} \mathrm{m} / z 115, \mathrm{C}_{10} \mathrm{H}_{8}^{+} \mathrm{m} / z 128, \mathrm{C}_{12} \mathrm{H}_{8}^{+} \mathrm{m} / z 152, \mathrm{C}_{13} \mathrm{H}_{9}^{+} \mathrm{m} / z 165, \mathrm{C}_{14} \mathrm{H}_{10}^{+}\right.$ $m / z 178, \mathrm{C}_{15} \mathrm{H}_{9}^{+} m / z$ 189) [99]. The separation of these two spectra was not possible because coal combustion emissions are released in the atmosphere in the same time with emission from wood burning. The amount coal burning in Romania is not significant based on the data from Eurostat [100] and World Data Atlas [101]. The coal used in Romania is the brown and lignite verities, which have a high content of wood [102]. 

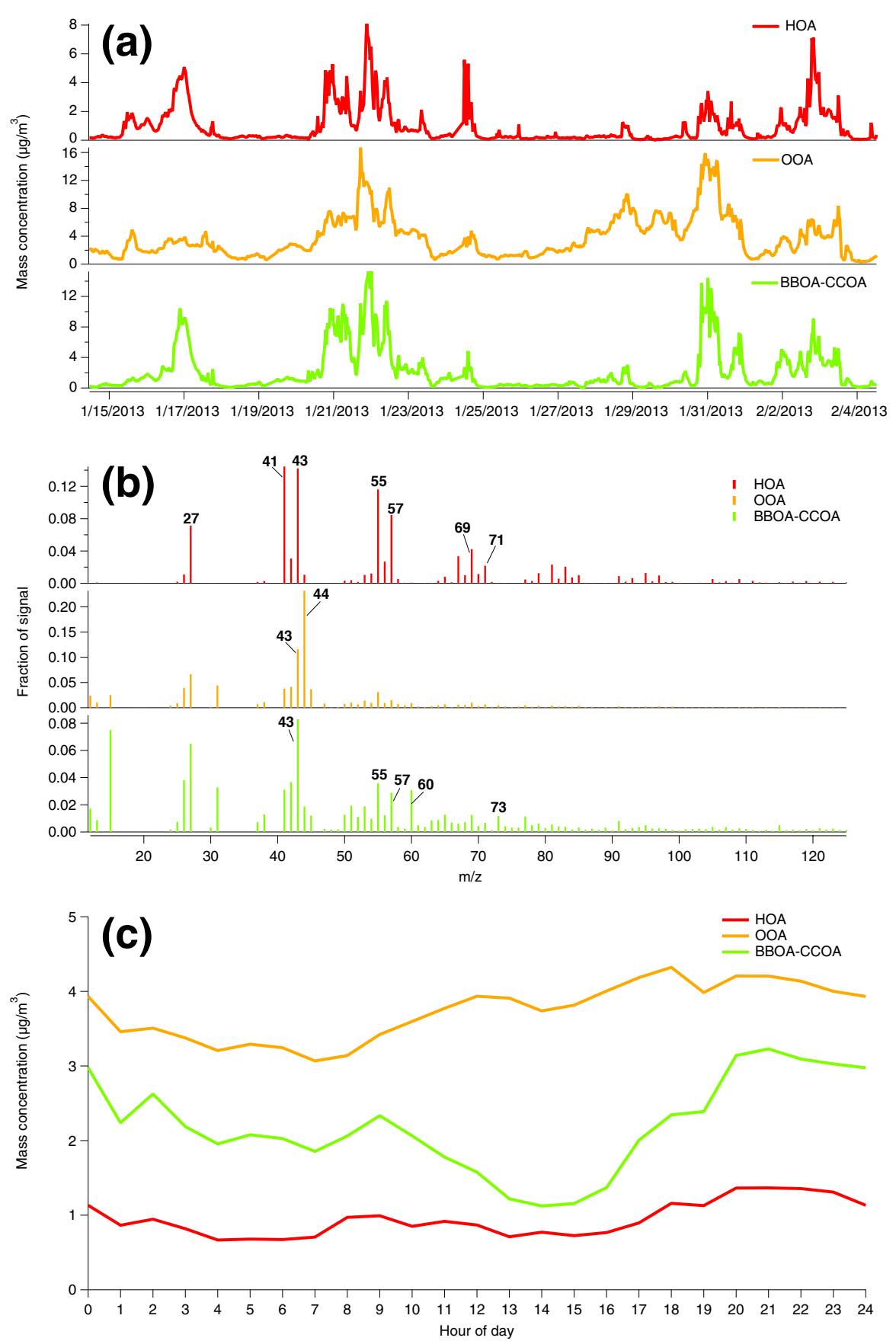

Figure 9. Positive matrix factorization result for winter (a) time series of the organic factors, (b) mass spectra of the organic factors, and (c) diurnal variation of the factors. Red-HOA, yellow-OOA, and green-BBOA-coal combustion OA (CCOA).

Additional filter-based analyses were conducted on samples obtained from 30 January-5 February 2013. These showed that elemental carbon from non-fossil ( $E C_{n f}$, derived from ${ }^{14} C$ analysis) origin correlates $\left(r^{2}=0.63\right)$ well with black carbon attributed to wood combustion (derived from aethalometer model) (Figure S12 in Supplementary Material) [103]. The coal combustion is only a minor fraction of the BBOA-CCOA factor. In the Măgurele area, the main combustion fuels are natural gas, wood and, in a lower proportion, fossil fuel. Radiocarbon analysis (i.e., ${ }^{14} \mathrm{C}$ analysis) shows that organic carbon from fossil origin is less than $9 \%$ of the total carbon. The non-fossil organic carbon represents $\sim 80 \%$ of the total carbon mass, being associated with biomass burning (Figure 10). The elemental carbon 
fraction $(\sim 11 \%)$ for all days is dominated by the non-fossil component, except for 2 February 2013 where an increase in the fraction of fossil fuel in elemental carbon can be observed (Figure 10).
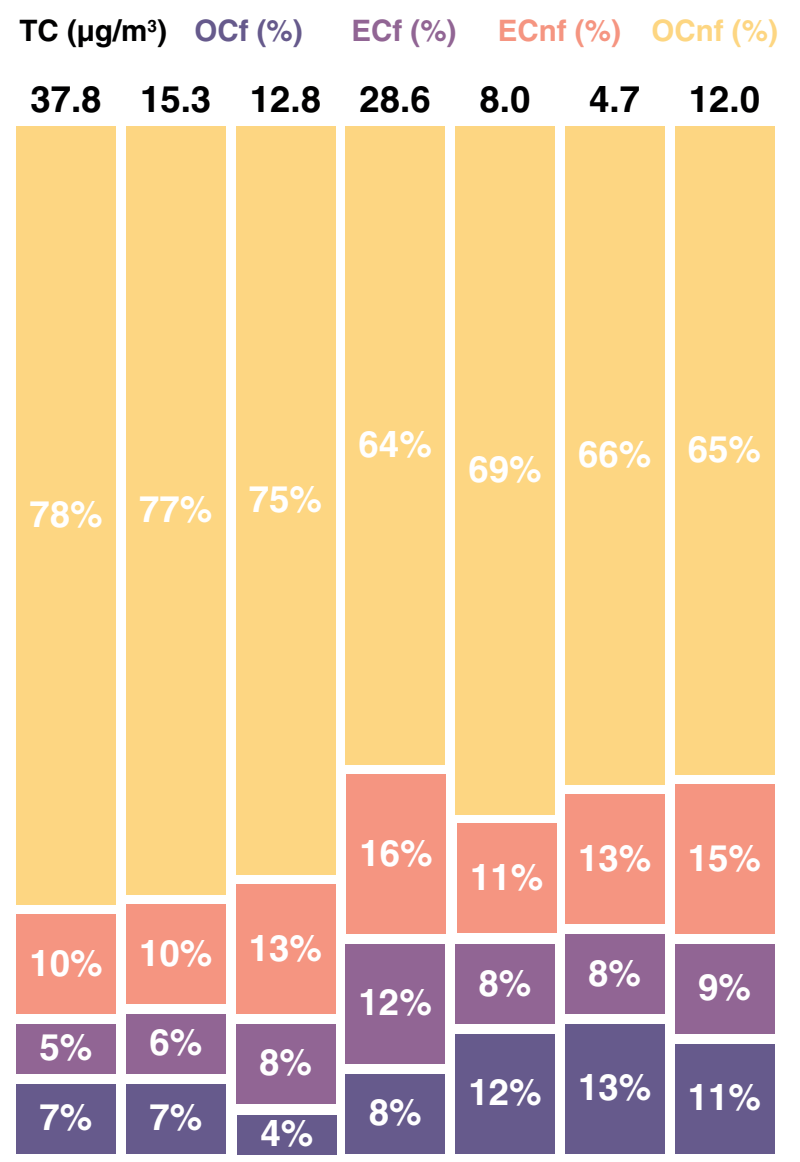

30 Jan 31 Jan 01 Feb 02 Feb 03 Feb 04 Feb 05 Feb

Figure 10. Relative fossil vs. non-fossil contributions based on ${ }^{14} \mathrm{C}$ analyses to the total carbon (TC). Black—values of daily TC concentration, blue-percentage of fossil organic carbon, purple-percentage of elemental carbon from fossil, orange-percentage of elemental carbon from non-fossil, yellow-percentage of non-fossil organic carbon.

The HOA factor identified is related to vehicle engine exhaust and is characterized by hydrocarbon ion series of $\mathrm{C}_{n} \mathrm{H}_{2 n+1}$ and $\mathrm{C}_{n} \mathrm{H}_{2 n-1}$ as also observed by, e.g., Crippa et al. [12] and Aiken et al. [90]. It contributes only a small fraction $(13.8 \%)$ to the total organic mass. The diurnal pattern contains typical signatures of HOA (e.g., rush hour peaks at 08:00-18:00 local time). Factor separation was based on the correlation with external tracers $\left(\mathrm{NO}_{x}\right)$. The constraining $a$-value for HOA was 0.55 for which the highest correlation with $\mathrm{NO}_{x}$ was $\mathrm{r}^{2}=0.66$ and 0.65 with $\mathrm{BC}_{f f}$ (source analysis from aethalometer data) (Figure S13 in Supplementary Material). Elemental carbon, from fossil fuel combustion (base on ${ }^{14} \mathrm{C}$ analysis) is highly correlated $\left(\mathrm{r}^{2}=0.96\right)$ with $\mathrm{BC}_{f f}$. The BBOA-CCOA has a higher correlation with $\mathrm{BC}_{w b}\left(\mathrm{r}^{2}=0.94\right)$. A good correlation was also found between elemental carbon and $\mathrm{BC}_{w b}\left(\mathrm{r}^{2}=0.63\right)$. The OOA is characterized by a high degree of oxidation and does not have high diurnal variability, being well correlated with the $\mathrm{SO}_{4}$ time series $\left(\mathrm{r}^{2}=0.58\right)$. For the period (i.e., 30 January- 5 February 2013) when ${ }^{14} \mathrm{C}$ analyses were available, total carbon contribution shows that the main component is represented by non-fossil fraction (Figure 10).

\section{Conclusions}

This article presents the first high resolution time-resolved measurements of submicron aerosol composition in Romania. Measurement campaigns using online aerosol mass spectrometry were 
conducted during winter and summer, showing significant seasonal differences. The total average loading of NR-PM $\mathrm{PM}_{1}$ is up to three times higher in winter than in summer. The NR-PM $\mathrm{PM}_{1}$ composition differs significantly between seasons. Organics (and sulfate) decreased from 53\% (26\%) during the summer to $49 \%(15 \%)$ during winter. In contrast, nitrate (and chloride) increased from $6 \%(1 \%)$ in summer to $19 \%(3 \%)$ in winter. High nitrate concentrations during winter are consistent with the influence of urban pollution and gas/particle partitioning.

Source apportionment results demonstrate that the dominant emissions sources have a strong seasonal dependence. Residential wood combustion and, to a lesser extent, coal is used for heating during winter, while BBOA long-range/regional transport can be present during summer. In summer, regional influences and agricultural activities represent the main sources of BBOA. Radiocarbon analysis (i.e., ${ }^{14} \mathrm{C}$ analysis) of aerosol collected during winter confirms an overwhelming contribution of non-fossil organic carbon to the total OA. Other identified sources included traffic and cooking, which could be separated from each other only in summer. The PBL height evolution influencing the NR-PM $\mathrm{PM}_{1}$ concentration could be identified during the summer season. The diurnal variation of the PBL height influences the dilution and the concentration processes.

This article, focused on evaluating the sources of organic compounds, highlights the main influences on the Măgurele site, during winter and summer. The main contributors are represented by oxidized organic fraction, with higher influence from regional areas during summer. A lower contribution was observed during winter, when SOA represented $\sim 55 \%$.

Future studies are necessary to investigate the long-term seasonality of aerosol sources at the Măgurele site to assess the evolution in time and the increase in concentration due to urbanisation processes. Such studies can be further used in conjunction with respiratory and cardiovascular incidence data to understand the impact of pollution on human health.

Supplementary Materials: The following are available online at http:/ /www.mdpi.com/2073-4433/11/4/385/s1. Figure S1: The relation between NR-PM 1 concentration and temperature; Figure S2: Back trajectories from HYSPLIT for 13 June ending at 09 UTC; Figure S3: Back trajectories from HYSPLIT for 9 July ending at 23 UTC; Figure S4: Back trajectories from HYSPLIT for 9 July ending at 18 UTC; Figure S5: Fires detected by MODIS between 9-13 July 2012; Figure S6: Temporal evolution of the Lidar Range Corrected Signal at 1064nm during summer time, temperature and organic fraction concentration time series; Figure S7: Temporal evolution of the Lidar Range Corrected Signal at 1064nm during winter time; Figure S8: Diurnal variation of POA and SOA concentrations for city influence during summer; Figure S9: f44 versus f43 colored by date (a) city influence; (b) regional influence during summer; Figure S10: Diurnal variation of POA and SOA concentrations for remote influence during summer; Figure S11: Diurnal variation of POA and SOA concentrations during winter; Figure S12: Correlation between (a) BC fossil fuel derived from Aethalometer data and fossil part of EC from ${ }^{14} \mathrm{C}$ analysis; (b) BC wood related derived from Aethalometer data and non- fossil EC derived from ${ }^{14} \mathrm{C}$ analysis; Figure S13: (a) Diurnal variation of $\mathrm{NO}_{x}$ and HOA concentrations; (b) Correlation between $\mathrm{NO}_{x}$ and $\mathrm{HOA}$ concentrations for winter time.

Author Contributions: Conceptualization, L.M. and J.V.; investigation, L.M. and J.V.; writing一original draft preparation, L.M.; writing-review and editing, J.V., J.S., A.S.H.P., C.A.M., S.S. and B.A.; visualization, B.A.; data curation, C.A.M., A.V., A.N. and A.D. supervision, J.S. and A.S.H.P.; All authors have read and agreed to the published version of the manuscript.

Funding: This research was funded by a grant from Switzerland through the Swiss Contribution to the enlarged European Union within the Romanian-Swiss Research Programme (RSRP); by the Romanian Ministry of Research and Innovation through Program I-Development of the national research development system, Subprogram 1.2-Institutional Performance-Projects of Excellence Financing in RDI, Contract No.19 PFE/17.10.2018, by the Romanian National Core Program Contract No.18N/2019; and by the European Regional Development Fund through the Competitiveness Operational Programme 2014-2020, POC-A.1-A.1.1.1-F-2015, project Research Centre for Environment and Earth Observation CEO-Terra, SMIS code 108109, contract No. 152/2016.

Acknowledgments: The authors gratefully acknowledge the COST Action "COLOSSAL" under grant agreement CA16109.

Conflicts of Interest: The authors declare no conflict of interest. 


\section{References}

1. Young, D.E.; Allan, J.D.; Williams, P.I.; Green, D.C.; Flynn, M.J.; Harrison, R.M.; Yin, J.; Gallagher, M.W.; Coe, H. Investigating the annual behaviour of submicron secondary inorganic and organic aerosols in London. Atmos. Chem. Phys. 2014, 15, 12031-12053. [CrossRef]

2. Leru, P.; Eftimie, A.M.; Thibaudon, M. First Allergenic Pollen Monitoring in Bucharest and Results of Three Years Collaboration with European Aerobiology Specialists. Rom. J. Intern. Med. 2018, 56, 27-33. [CrossRef] [PubMed]

3. Core Writing Team.; Pachauri, R.; Meyer, L. Climate Change 2014: Synthesis Report. Contribution of Working Groups I, II and III to the Fifth Assessment Report of the Intergovernmental Panel on Climate Change; IPCC: Geneva, Switzerland, 2014; p. 1535.

4. Stocker, T.; Qin, D.; Plattner, G.K.; Tignor, M.; Allen, S.; Boschung, J.; Nauels, A.; Xia, Y.; Bex, V.; Midgley, P. Climate Change 2013: The Physical Science Basis. Contribution of Working Group I to the Fifth Assessment Report of the Intergovernmental Panel on Climate Change; Cambridge University Press: Cambridge, UK; New York, NY, USA, 2013; p. 1535.

5. Tao, J.; Zhang, L.; Gao, J.; Wang, H.; Chai, F.; Wang, S. Aerosol chemical composition and light scattering during a winter season in Beijing. Atmos. Environ. 2015, 110, 36-44. [CrossRef]

6. Li, Y.J.; Lee, B.P.; Su, L.; Fung, J.C.H.; Chan, C. Seasonal characteristics of fine particulate matter (PM) based on high-resolution time-of-flight aerosol mass spectrometric (HR-ToF-AMS) measurements at the HKUST Supersite in Hong Kong. Atmos. Chem. Phys. 2015, 15, 37-53. [CrossRef]

7. Tsimpidi, A.P.; Karydis, V.A.; Pandis, S.N.; Lelieveld, J. Global combustion sources of organic aerosols: Model comparison with 84 AMS factor analysis data sets. Atmos. Chem. Phys. 2016, 16, 8939-8962. [CrossRef]

8. Zhang, Q.; Jimenez, J.L.; Canagaratna, M.R.; Allan, J.D.; Coe, H.; Takami, A.; Middlebrook, A.M.; Sun, Y.L.; Dzepina, K.; Dunlea, E.; et al. Ubiquity and dominance of oxygenated species in organic aerosols in anthropogenically-influenced Northern Hemisphere midlatitudes. Geophys. Res. Lett. 2007, 34, L13801. [CrossRef]

9. Simoneit, B.; Kobayashi, M.; Mochida, M.; Kawamura, K.; Lee, M.; Lim, H.J.; Turpin, B.; Komazaki, Y. Composition and major sources of organic compounds of aerosol particulate matter sampled during ACE-Asia campaign. J. Geophys. Res. 2004, 109, D19S10. [CrossRef]

10. Canagaratna, M.R.; Jayne, J.T.; Jiménez, J.L.; Allan, J.D.; Alfarra, M.R.; Zhang, Q.; Onasch, T.B.; Drewnick, F.; Coe, H.; Middlebrook, A.; et al. Chemical and Microphysical Characterization of ambient aerosols with the Aerodyne Aerosol Mass Spectrometer. Mass Spectrom. Rev. 2007, 26, 185-222. [CrossRef]

11. Minguillón, M.C.; Perron, N.; Querol, X.; Szidat, S.; Fahrni, S.M.; Alastuey, A.; Jimenez, J.L.; Mohr, C.; Ortega, A.M.; Day, D.A.; et al. Fossil versus contemporary sources of fine elemental and organic carbonaceous particulate matter during the DAURE campaign in Northeast Spain. Atmos. Chem. Phys. 2011, 11, 12067-12084. [CrossRef]

12. Crippa, M.; DeCarlo, P.F.; Slowik, J.G.; Mohr, C.; Heringa, M.F.; Chirico, R.; Poulain, L.; Freutel, F.; Sciare, J.; Cozic, J.; et al. Wintertime aerosol chemical composition and source apportionment of the organic fraction in the metropolitan area of Paris. Atmos. Chem. Phys. 2013, 13, 961-981. [CrossRef]

13. He, L.Y.; Huang, X.; Xue, L.; Hu, M.; Lin, Y.; Zheng, J.; Zhang, R.; Zhang, Y. Submicron aerosol analysis and organic source apportionment in an urban atmosphere in Pearl River Delta of China using high-resolution aerosol mass spectrometry. J. Geophys. Res. 2011, 116, D12304. [CrossRef]

14. He, L.Y.; Lin, Y.; Huang, X.F.; Guo, S.; Xue, L.; Su, Q.; Hu, M.; Luan, S.J.; Zhang, Y.H. Characterization of high-resolution aerosol mass spectra of primary organic aerosol emissions from Chinese cooking and biomass burning. Atmos. Chem. Phys. 2010, 10, 11535-11543. [CrossRef]

15. Sun, Y.; Wang, Z.; Dong, H.; Yang, T.; Li, J.; Pan, X.; Chen, P.; Jayne, J.T. Characterization of summer organic and inorganic aerosols in Beijing, China with an Aerosol Chemical Speciation Monitor. Atmos. Environ. 2012, 51, 250-259. [CrossRef]

16. Sun, Y.; Zhang, Q.; Schwab, J.J.; Demerjian, K.L.; Chen, W.; Bae, M.S.; Hung, H.M.; Hogrefe, O.; Frank, B.; Rattigan, O.V.; et al. Characterization of the sources and processes of organic and inorganic aerosols in New York city with a high-resolution time-of-flight aerosol mass spectrometer. Atmos. Chem. Phys. 2011, 11, 1581-1602. [CrossRef] 
17. Slowik, J.G.; Vlasenko, A.; McGuire, M.; Evans, G.J.; Abbatt, J. Simultaneous factor analysis of organic particle and gas mass spectra: AMS and PTR-MS measurements at an urban site. Atmos. Meas. Tech. 2010, 10, 1969-1988. [CrossRef]

18. Mohr, C.; DeCarlo, P.F.; Heringa, M.F.; Chirico, R.; Slowik, J.G.; Richter, R.; Reche, C.; Alastuey, A.; Querol, $X . ;$ Seco, R.; et al. Identification and quantification of organic aerosol from cooking and other sources in Barcelona using aerosol mass spectrometer data. Atmos. Chem. Phys. 2012, 12, 1649-1665. [CrossRef]

19. Schäfer, K.; Elsasser, M.; Arteaga-Salas, J.M.; Gu, J.; Pitz, M.; Schnelle-Kreis, J.; Cyrys, J.; Emeis, S.; Prévôt, A.; Zimmermann, R. Source apportionment and the role of meteorological conditions in the assessment of air pollution exposure due to urban emissions. Atmos. Chem. Phys. Discuss. 2014, 14, 2235-2275. [CrossRef]

20. Caggiano, R.; Macchiato, M.; Trippetta, S. Levels, chemical composition and sources offine aerosol particles (PM1) in an area ofthe Mediterranean basin. Sci. Total Environ. 2010, 408, 884-895. [CrossRef]

21. Pateraki, S.; Asimakopoulos, D.; Maggos, T.; Assimakopoulos, V.; Bougiatioti, A.; Bairachtari, K.; Vasilakos, C.; Mihalopoulos, N. Chemical characterization, sources and potential health risk of PM2.5 and PM1 pollution across the Greater Athens Area. Chemosphere 2020, 241, 125026. [CrossRef]

22. Yubero, E.; Galindo, N.; Nicolás, J.F.C.J.; Calzolai, G.; Lucarelli, F. Temporal variations of PM1 major components in an urban street canyon. Environ. Sci. Pollut. Res. 2015, 22, 13328-13335. [CrossRef]

23. Stojić, A.; Stojić, S.; S̆oštarić, A.; Iliv, L.; Mijić, Z.; Rajšić, S. Characterization of VOC sources in an urban area based on PTR-MS measurements and receptor modelling. Environ. Sci. Pollut. R. 2015, 22, 13137-13152. [CrossRef] [PubMed]

24. Perrone, M.; Vratolis, S.; Georgieva, E.; Török, S.; Šega, K.; Veleva, B.; Osán, J.; Bešlić, I.; Kertész, Z.; Pernigotti, D.; et al. Sources and geographic origin of particulate matter in urban areas of the Danube macro-region: The cases of Zagreb (Croatia), Budapest (Hungary) and Sofia (Bulgaria). Sci. Total. Environ. 2018, 619-620, 1515-1529. [CrossRef] [PubMed]

25. Vasilescu, J.; Mărmureanu, L.; Nemuc, A.; Nicolae, D.; Talianu, C. Seasonal variation of the aerosol chemical composition in a Romanian peri-urban area. Environ. Eng. Manag. J. 2017, 16, 2491-2496.

26. Nicolae, D.; Nemuc, A.; Müller, D.; Talianu, C.; Vasilescu, J.; Belegante, L.; Kolgotin, A. Characterization of fresh and aged biomass burning events using multiwavelength Raman lidar and mass spectrometry. J. Geophys. Res. Atmos. 2013, 118, 2956-2965. [CrossRef]

27. ACTRIS. Aerosols, Clouds, and Trace gases Research InfraStructure. 2020. Available online: http://www. actris.eu (accessed on 1 March 2020).

28. EMEP. European Monitoring and Evaluation Programme. 2020. Available online: http://www.emep.int (accessed on 1 March 2020).

29. Schlag, P.; Kiendler-Scharr, A.; Blom, M.J.; Canonaco, F.; Henzing, J.S.; Moerman, M.M.; Prévôt, A.; Holzinger, R. Aerosol source apportionment from 1-year measurements at the CESAR tower in Cabauw, The Netherlands. Atmos. Chem. Phys. 2016, 16, 8831-8847. [CrossRef]

30. Wang, Y.; Sartelet, K.N.; Bocquet, M.; Chazette, P.; Sicard, M.; D'Amico, G.; Léon, J.F.; Alados-Arboledas, L.; Amodeo, A.; Augustin, P.; et al. Assimilation of lidar signals: Application to aerosol forecasting in the western Mediterranean basin. Atmos. Chem. Phys. 2014, 14, 12031-12053. [CrossRef]

31. Henry, R.; Lewis, C.; Hopke, P.; Williamson, H. Review of receptor model fundamental. Atmos. Environ. 1984, 18, 1507-1515. [CrossRef]

32. Paatero, P. The Multilinear engine-A table-driven, least squares program for solving multilinear Problems, Including the n-Way Parallel Factor Analysis Model. J. Comput. Graph. Stat. 1999, 8, 854-888. [CrossRef]

33. Canonaco, F.; Crippa, M.; Slowik, J.G.; Baltensperger, U.; Prévôt, A.S.H. SoFi, an IGOR-based interface for the efficient use of the generalized multilinear engine (ME-2) for the source apportionment: ME-2 application to aerosol mass spectrometer data. Atmos. Meas. Tech. 2013, 6, 3649-3661. [CrossRef]

34. Lanz, V.; Alfarra, M.; Baltensperger, U.; Buchmann, B.; Hueglin, C.; Szidat, S.; Wehrli, M.; Wacker, L.; Weimer, S.; Caseiro, A.; et al. Source Attribution of Submicron Organic Aerosols During Wintertime Inversions by Advanced Factor Analysis of Aerosol Mass Spectra. Environ. Sci. Technol. 2008, 42, 214-220. [CrossRef]

35. Zhu, Q.; Huang, X.F.; Cao, L.M.; Wei, L.T.; Zhang, B.; He, L.Y.; Elser, M.; Canonaco, F.; Slowik, J.G.; Bozzetti, C.; et al. Improved source apportionment of organic aerosols in complex urban air pollution using the multilinear engine (ME-2). Atmos. Meas. Tech. 2018, 11, 1049-1060. [CrossRef] 
36. Zotter, P.; Ciobanu, V.G.; Zhang, Y.L.; El-Haddad, I.; Macchia, M.; Daellenbach, K.R.; Salazar, G.A.; Huang, R.J.; Wacker, L.; Hueglin, C.; et al. Radiocarbon analysis of elemental and organic carbon in Switzerland during winter-smog episodes from 2008 to 2012-Part 1: Source apportionment and spatial variability. Atmos. Chem. Phys. 2014, 14, 13551-13570. [CrossRef]

37. Crilley, L.R.; Bloss, W.J.; Yin, J.; Beddows, D.C.S.; Harrison, R.M.; Allan, J.D.; Young, D.E.; Flynn, M.; Williams, P.; Zotter, P.; et al. Sources and contributions of wood smoke during winter in London: Assessing local and regional influences. Atmos. Chem. Phys. 2015, 15, 3149-3171. [CrossRef]

38. Petit, J.E.; Favez, O.; Sciare, J.; Crenn, V.; Sarda-Estève, R.; Bonnaire, N.; Močnik, G.; Dupont, J.C.; Haeffelin, M.; Leoz-Garziandia, E. Two years of near real-time chemical composition of submicron aerosols in the region of Paris using an Aerosol Chemical Speciation Monitor (ACSM) and a multi-wavelength Aethalometer. Atmos. Chem. Phys. 2015, 15, 2985-3005. [CrossRef]

39. Krzywanski, J.; Rajczyk, R.; Nowak, W. Model Research of Gas Emissions From Lignite and Biomass Co-Combustion in a Large Scale CFB Boiler. Chem. Process. Eng. 2014, 35, 217-231. [CrossRef]

40. Nowak, W.; Muskala, J.K.; Czakiert, T. The Research of CFB Boiler Operation for Oxygen Enhanced Dried Lignite Combustion. In Proceedings of the 10th International Conference on Circulating Fluidized Beds and Fluidization Technology-CFB-10, ECI Symposium Serie, Sun River, OR, USA, 1-5 May 2011.

41. Belegante, L.; Nicolae, D.; Nemuc, A.; Talianu, C.; Derognat, C. Retrieval of the Boundary Layer Height from Active and Passive Remote Sensors. Comparison with a NWP Model. Acta Geophys. 2014, 62, 276-289. [CrossRef]

42. Marin, C.; Mărmureanu, L.; Radu, C.; Dandocsi, A.; Stan, C.; Țoancă, F.; Preda, L.; Antonescu, B. Wintertime Variations of Gaseous Atmospheric Constituents in Bucharest Peri-Urban Area. Atmosphere 2019, 10, 478. [CrossRef]

43. Mărmureanu, L.; Deaconu, L.; Vasilescu, J.; Ajtai, N.; Talianu, C. Combined optoelectronic methods used in the monitoring of so2 emissions and imissions. Environ. Eng. Manag. J. 2013, 12, 277-282.

44. Romanian Ministry of Environment. Authorization No. 104 / 13.02.2013 on green gases emissions. 2019. Available online: http:/ / mmediu.ro/new/wp-content/uploads/2014/10/2014-10-20_Autorizatie_GES_ 2013-ELCEN_CTE_SUD_rev_iulie_2013.pdf (accessed on 8 November 2019).

45. Burcea, S.; Cheval, S.; Dumitrescu, A.; Antonescu, B.; Bell, A.; Breza, T. Comparison between radar estimated rain gauge measured precipitation in the Moldavian Plateau. Environ. Eng. Manag. J. 2012, 4, 723-731. [CrossRef]

46. Antonescu, B.; Burcea, S.; Tanase, A. Forecasting the onset of cloud-to-ground lightning using radar and upper-air data in Romania. Int. J. Climatol. 2013, 33, 1579-1584. [CrossRef]

47. Nemuc, A.; Vasilescu, J.; Talianu, C.; Belegante, L.; Nicolae, D. Assessment of aerosol's mass concentrations from measured linear particle depolarization ratio (vertically resolved) and simulations. Atmos. Meas. Tech. 2013, 6, 3243-3255. [CrossRef]

48. Mărmureanu, L.; Marin, C.; Andrei, S.; Antonescu, B.; Ene, D.; Boldeanu, M.; Vasilescu, J.; Viţelaru, C.; Cadar, O.; Levei, E. Orange Snow-A Saharan Dust Intrusion over Romania During Winter Conditions. Remote Sens. 2019, 11, 2466. [CrossRef]

49. Sicard, M.; D’Amico, G.; Comerón, A.; Mona, L.; Alados-Arboledas, L.; Amodeo, A.; Baars, H.; Baldasano, J.M.; Belegante, L.; Binietoglou, I.; et al. EARLINET: Potential operationality of a research network. Atmos. Meas. Tech. 2015, 8, 4587-4613. [CrossRef]

50. Holzinger, R. PTRwid: A new widget tool for processing PTR-TOF-MS data. Atmos. Meas. Tech. 2015, 8, 3903-3922. [CrossRef]

51. Drewnick, F.; Hings, S.; DeCarlo, P.; Jayne, J.; Gonin, M.; Fuhrer, K.; Weimer, S.; Jimenez, J.; Demerjian, K.; Borrmann, S.; et al. A new Time-of-Flight Aerosol Mass Spectrometer (ToF-AMS): Instrument Description and First Field Deployment. Aerosol. Sci. Tech. 2005, 39, 637-658. [CrossRef]

52. Zhang, J.K.; Sun, Y.; Liu, Z.R.; Ji, D.S.; Hu, B.; Liu, Q.; Wang, Y.S. Characterization of submicron aerosols during a month of serious pollution in Beijing, 2013. Atmos. Chem. Phys. 2014, 14, 2887-2903. [CrossRef]

53. Murphy, D.M. The effects of molecular weight and thermal decomposition on the sensitivity of a thermal desorption aerosol mass spectrometer. Aerosol Sci. Technol. 2016, 50, 118-125. [CrossRef]

54. Bahreini, R.; Ervens, B.; Middlebrook, A.M.; Warneke, C.; de Gouw, J.A.; DeCarlo, P.F.; Jimenez, J.L.; Brock, C.A.; Neuman, J.A.; Ryerson, T.B.; et al. Organic aerosol formation in urban and industrial plumes near Houston and Dallas, Texas. J. Geophys. Res. Atmos. 2009, 114. [CrossRef] 
55. Dandocsi, A.; Preda, L.; Nicolae, D.; Nemuc, A. Planetary boundary layer investigation from lidar measurements over Bucuharest. U.P.B. Sci. Bull. 2012, 78, 265-274.

56. Ştefan, S.; Radu, C.; Belegante, L. Analysis of air quality in two sites with different local conditions. Environ. Eng. Manag. J. 2013, 12, 371-379. [CrossRef]

57. Drinovec, L.; Močnik, G.; Zotter, P.; Prévôt, A.S.H.; Ruckstuhl, C.; Coz, E.; Rupakheti, M.; Sciare, J.; Müller, T.; Wiedensohler, A.; et al. The "dual-spot" Aethalometer: An improved measurement of aerosol black carbon with real-time loading compensation. Atmos. Meas. Tech. 2015, 8, 1965-1979. [CrossRef]

58. Sandradewi, J.; Prévôt, A.S.H.; Szidat, S.; Perron, N.; Lanz, V.; Weingartner, E.; Baltensperger, U. Using aerosol light absorption measurements for the quantitative determination of wood burning and traffic emission contributions to particulate matter. Environ. Sci. Technol. 2008, 42, 3316-3323. [CrossRef] [PubMed]

59. Kalogridis, A.C.; Vratolis, S.; Liakakou, E.; Gerasopoulos, E.; Mihalopoulos, N.; Eleftheriadis, K. Assessment of wood burning versus fossil fuel contribution to wintertime black carbon and carbon monoxide concentrations in Athens, Greece. Atmos. Chem. Phys. 2018, 18, 10219-10236. [CrossRef]

60. Bond, T.C.; Bergstrom, R.W. Light absorption by carbonaceous particles: An investigative review. Aerosol Sci. Technol. 2006, 40, 27-67. [CrossRef]

61. Lewis, K.; Arnott, W.P.; Moosmuller, H.; Wold, C.E. Strong spectral variation of biomass smoke light absorption and single scattering albedo observed with a novel dual-wavelength photoacoustic instrument. J. Geophys. Res. 2008, 113, D16203. [CrossRef]

62. Stein, A.; Draxler, R.; Rolph, G.; Stunder, B.; Cohen, M.; Ngan, F. NOAA's HYSPLIT atmospheric transport and dispersion modeling system. Bull. Am. Meteor. Soc. 2015, 96, 2059-2077. [CrossRef]

63. Davies, D.; Kumar, S.; Descloitres, J. Global fire monitoring using MODIS near-real-time satellite data. GIM Int. 2004, 18, 41-43.

64. Szidat, S.; Salazar, G.A.; Vogel, E.; Battaglia, M.; Wacker, L.; Synal, H.-A.; Türler, A. ${ }^{14}$ C Analysis and Sample Preparation at the New Bern Laboratory for the Analysis of Radiocarbon with AMS (LARA). Radiocarbon 2014, 52, 561-566. [CrossRef]

65. Zhang, Y.L.; Perron, N.; Ciobanu, V.G.; Zotter, P.; Minguillón, M.C.; Wacker, L.; Prévôt, A.S.H.; Baltensperger, U.; Szidat, $\mathrm{S}$. On the isolation of OC and EC and the optimal strategy of radiocarbon-based source apportionment of carbonaceous aerosols. Atmos. Chem. Phys. 2012, 12, 10841-10856. [CrossRef]

66. Paatero, P. Least squares formulation of robust nonnegative factor analysis. Chemom. Intell. Lab. Syst. 1997, 37, 23-35. [CrossRef]

67. Paatero, P.; Eberly, S.; Brown, S.G.; Norris, G.A. Methods for estimating uncertainty in factor analytic solutions. Atmos. Meas. Tech. 2014, 7, 781-797. [CrossRef]

68. Fröhlich, R.; Crenn, V.; Setyan, A.; Belis, C.A.; Canonaco, F.; Favez, O.; Riffault, V.; Slowik, J.G.; Aas, W.; Äijälä, M.; et al. ACTRIS ACSM intercomparison-Part 2: Intercomparison of ME-2 organic source apportionment results from 15 individual, co-located aerosol mass spectrometers. Atmos. Meas. Tech. 2015, 8, 2555-2576. [CrossRef]

69. Aurela, M.; Saarikoski, S.; Niemi, J.V.; Canonaco, F.; Prévôt, A.; Frey, A.; Carbone, S.; Kousa, A.; Hillamo, R. Chemical and source characterization of submicron particles at residential and traffic sites in the Helsinki Metropolitan Area, Finland. Aerosol Air Qual. Res. 2015, 15, 1213-1226. [CrossRef]

70. Allan, J.D.; Delia, A.E.; Coe, H.; Bower, K.N.; Alfarra, M.R.; Jimenez, J.L.; Middlebrook, A.M.; Drewnick, F.; Onasch, T.B.; Canagaratna, M.R.; et al. A generalised method for the extraction of chemically resolved mass spectra from Aerodyne aerosol mass spectrometer data. J. Aerosol Sci. 2004, 35, 909-922. [CrossRef]

71. Ulbrich, I.M.; Canagaratna, M.R.; Zhang, Q.; Worsnop, D.R.; Jimenez, J.L. Interpretation of organic components from Positive Matrix Factorization of aerosol mass spectrometric data. Atmos. Chem. Phys. 2009, 9, 2891-2918. [CrossRef]

72. Crippa, M.; Canonaco, F.; Lanz, V.A.; PÄijälä, M.; Allan, J.D.; Carbone, S.; Capes, G.; Ceburnis, D.; Dall'Osto, M.; Day, D.A.; et al. Organic aerosol components derived from 25 AMS data sets across Europe using a consistent ME-2 based source apportionment approach. Atmos. Chem. Phys. 2014, 14, 6159-6176. [CrossRef]

73. Canonaco, F.; Slowik, J.G.; Baltensperger, U.; Prévôt, A.S.H. Seasonal differences in oxygenated organic aerosol composition: Implications for emissions sources and factor analysis. Atmos. Chem. Phys. 2015, 15, 6993-7002. [CrossRef] 
74. Ots, R.; Vieno, M.; Allan, J.D.; Reis, S.; Nemitz, E.; Young, D.E.; Coe, H.; Di Marco, C.; Detournay, A.; Mackenzie, I.A.; et al. Model simulations of cooking organic aerosol (COA) over the UK using estimates of emissions based on measurements at two sites in London. Atmos. Chem. Phys. 2016, 16, 13773-13789. [CrossRef]

75. Jimenez, J.L.; Canagaratna, M.R.; Donahue, N.M.; Prévôt, A.S.H.; Zhang, Q.; Kroll, J.H.; DeCarlo, P.F.; Allan, J.D.; Coe, H.; Ng, N.L.; et al. Evolution of Organic Aerosols in the Atmosphere. Science 2009, 326, 1525-1529. [CrossRef]

76. Wang, H.; Wang, X.; Yang, X.; Li, W.; Xue, L.; Wang, T.; Chen, J.; Wang, W. Mixed Chloride Aerosols and their Atmospheric Implications: A Review. Aerosol Air Qual. Res. 2017, 17, 878-887. [CrossRef]

77. Ianniello, A.; Spataro, F.; Esposito, G.; Allegrini, I.; Rantica, E.; Ancora, M.P.; Hu, M.; Zhu, T. Occurrence of gas phase ammonia in the area of Beijing (China). Atmos. Chem. Phys. 2010, 10, 9487-9503. [CrossRef]

78. Behera, S.; Sharma, M.; Aneja, V.; Balasubramanian, R. Ammonia in the atmosphere: A review on emission sources, atmospheric chemistry and deposition on terrestrial bodies. Environ. Sci. Pollut. Res. Int. 2013, 20. [CrossRef] [PubMed]

79. Jian, Y.; Fu, T.M. Injection heights of springtime biomass-burning plumes over peninsular Southeast Asia and their impacts on long-range pollutant transport. Atmos. Chem. Phys. 2014, 14, 3977-3989. [CrossRef]

80. Fromm, M.; Bevilacqua, R.; Servranckx, R.; Rosen, J.; Thayer, J.P.; Herman, J.; Larko, D. Pyro-cumulonimbus injection of smoke to the stratosphere: Observations and impact of a superblowup in northwestern Canada on 3-4 August 1998. J. Geophys.Res. 2005, 110, D08205. [CrossRef]

81. Samaras, S.; Nicolae, D.; Böckmann, C.; Vasilescu, J.; Binietoglou, I.; Labzovskii, L.; Țoanca, F.; Papayannis, A. Using Raman-lidar-based regularized microphysical retrievals and Aerosol Mass Spectrometer measurements for the characterization of biomass burning aerosols. J. Comput. Phys. 2015, 299, 156-174. [CrossRef]

82. Duduş, S. Dealu Spirii. Curaj si Devotament; Inspectoratul pentru Situatii de Urgenta "DEALU SPIRII" al Municipiului: Bucuresti, Romania, 2014; p. 140.

83. Galindo, N.; Yubero, E.; Clemente, A.; Nicolás, J.; Navarro-Selma, B.; Crespo, J. Insights into the origin and evolution of carbonaceous aerosols in a Mediterranean urban environment. Chemosphere 2019, 235, 636-642. [CrossRef]

84. Cubison, M.J.; Ortega, A.M.; Hayes, P.L.; Farmer, D.K.; Day, D.; Lechner, M.J.; Brune, W.H.; Apel, E.; Diskin, G.S.; Fisher, J.A.; et al. Effects of aging on organic aerosol from open biomass burning smoke in aircraft and laboratory studies. Atmos. Chem. Phys. 2011, 11, 12049-12064. [CrossRef]

85. Zhang, Y.; Sun, J.; Zhang, X.; Shen, X.; Wang, T.; Qin, M. Seasonal characterization of components and size distributions for submicron aerosols in Beijing. Sci. China Earth Sci. 2012, 56, 890-900. [CrossRef]

86. Finlayson-Pitts, B.J.; Pitts, J.N., Jr. Chemistry of the Upper and Lower Atmosphere, Theory, Experiments, and Applications; Elsevier Inc.: Amsterdam, The Netherlands, 2000; p. 969.

87. Grîu, T.; Lunguleasa, A. Economics consideration on wooden biomass Consumption. In Proceedings of the International Conference of Scientific Paper AFASES, Brasov, Romania, 22-24 May 2014.

88. Matthias, V.; Balis, D.; Bösenberg, J.; Eixmann, R.; Iarlori, M.; Komguem, L.; Mattis, I.; Papayannis, A.; Pappalardo, G.; Perrone, M.R.; et al. Vertical aerosol distribution over Europe: Statistical analysis of Raman lidar data from 10 European Aerosol Research Lidar Network (EARLINET) stations. J. Geophys. Res. 2004, 109, D18201. [CrossRef]

89. Zhang, Q.; Worsnop, D.R.; Canagaratna, M.R.; Jimenez, J.L. Hydrocarbon-like and oxygenated organic aerosols in Pittsburgh: Insights into sources and processes of organic aerosols. Atmos. Chem. Phys. 2005, 5, 3289-3311. [CrossRef]

90. Aiken, A.; Salcedo, D.; Cubison, M.; Huffman, J.A.; DeCarlo, P.; Ulbrich, I.M.; Docherty, K.S.; Sueper, D.; Kimmel, J.R.; Worsnop, D.R.; et al. Mexico City aerosol analysis during MILAGRO using high resolution aerosol mass spectrometry at the urban supersite (T0)_Part 1: Fine particle composition and organic source apportionment. Atmos. Chem. Phys. 2009, 9, 6633-6653. [CrossRef]

91. Geicu, A.; Cândea, I. (Eds.) Clima României (The Climate of Romania), Romanian National Meteorological Administration; Romanian Academy Press: Bucharest, Romania, 2008; p. 366.

92. Lei, L.; Xie, C.; Wang, D.; Yao, H.; Wang, Q.; Zhou, W.; Hu, W.; Fu, P.; Chen, Y.; Pan, X.; et al. Fine particle characterization in a coastal city in China: Composition, sources, and impacts of industrial emissions. Atmos. Chem. Phys. 2020, 20, 2877-2890. [CrossRef] 
93. Hennigan, C.J.; Sullivan, A.P.; Collett, J., Jr.; Robinson, A.L. Levoglucosan stability in biomass burning particles exposed to hydroxyl radicals. Geophys. Res. Lett. 2010, 37, L09806. [CrossRef]

94. Ng, N.L.; Canagaratna, M.R.; Jimenez, J.L.; Chhabra, P.S.; Seinfeld, J.H.; Worsnop, D.R. Changes in organic aerosol composition with aging inferred from aerosol mass spectra. Atmos. Chem. Phys. 2011, 11, 6465-6474. [CrossRef]

95. Hao, L.Q.; Kortelainen, A.; Romakkaniemi, S.; Portin, H.; Jaatinen, A.; Leskinen, A.; Komppula, M.; Miettinen, P.; Sueper, D.; Pajunoja, A.; et al. Atmospheric submicron aerosol composition and particulate organic nitrate formation in a boreal forestland-urban mixed region. Atmos. Chem. Phys. 2014, 14, 13483-13495. [CrossRef]

96. Duan, J.; Huang, R.J.; Lin, C.; Dai, W.; Wang, M.; Gu, Y.; Wang, Y.; Zhong, H.; Zheng, Y.; Ni, H.; et al. Distinctions in source regions and formation mechanisms of secondary aerosol in Beijing from summer to winter. Atmos. Chem. Phys. 2019, 19, 10319-10334. [CrossRef]

97. Xing, L.; Wu, J.; Elser, M.; Tong, S.; Liu, S.; Li, X.; Liu, L.; Cao, J.; Zhou, J.; El-Haddad, I.; et al. Wintertime secondary organic aerosol formation in Beijing-Tianjin-Hebei (BTH): Contributions of HONO sources and heterogeneous reactions. Atmos. Chem. Phys. 2019, 19, 2343-2359. [CrossRef]

98. Bruns, E.A.; Krapf, M.; Orasche, J.; Huang, Y.; Zimmermann, R.; Drinovec, L.; Močnik, G.; El-Haddad, I.; Slowik, J.G.; Dommen, J.; et al. Characterization of primary and secondary wood combustion products generated under different burner loads. Environ. Sci. Technol. 2015, 42, 3316-3323. [CrossRef]

99. Hu, W.W.; Hu, M.; Yuan, B.; Jimenez, J.L.; Tang, Q.; Peng, J.F.; Hu, W.; Shao, M.; Wang, M.; Zeng, L.M.; et al. Insights on organic aerosol aging and the influence of coal combustion at a regional receptor site of central eastern China. Atmos. Chem. Phys. 2013, 13, 10095-10112. [CrossRef]

100. Eurostat. European Statistics. 2020. Available online: https://ec.europa.eu/eurostat/data/database (accessed on 1 March 2020).

101. Knoema Enterprise Data Solutions. World Data Atlas. 2020. Available online: https://knoema.com/atlas / Romania/topics/Energy/Coal/Coal-primary-consumption (accessed on 1 March 2020).

102. Cruceru, M.; Voronca, M.; Popescu, L.; Diaconu, B. GHG emissions reduction by using miscanth usgig anteus as additional fuel in existing coal fired boilers. Ann. Constantin Brancusi Univ. Targu Jiu Eng. Ser. 2013, 1, 9-16.

103. Zotter, P.; Herich, H.; Gysel, M.; El-Haddad, I.; Zhang, Y.; Močnik, G.; Hüglin, C.; Baltensperger, U.; Szidat, S.; Prévôt, A. Evaluation of the absorption Ångström exponents for traffic and wood burning in the Aethalometer-based source apportionment using radiocarbon measurements of ambient aerosol. Atmos. Chem. Phys. 2017, 17, 4229-4249. [CrossRef] 